\title{
Interactions between the brain and the immune system in pain and inflemmation
}

Joanna Zajidel

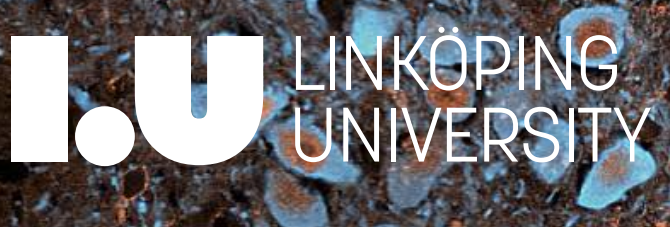




\title{
Interactions between the brain and the immune system in pain and inflammation
}

\author{
Joanna Zajdel
}

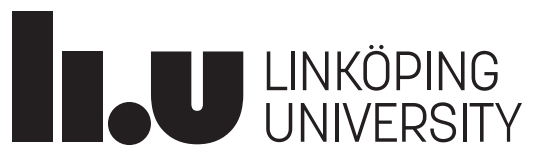

Linköping University

Faculty Of Medicine And Health Sciences

Department of Clinical and Experimental Medicine

Center for Social and Affective Neuroscience

SE-581 83 Linköping, Sweden

Linköping 2019 


\section{Edition 1:1}

(C) Joanna Zajdel, 2019

ISBN 978-91-7685-084-8

ISSN 0345-0082

Published articles have been reprinted with permission from the respective copyright holder.

Typeset using $\mathrm{X}_{4} \mathrm{~T}_{\mathrm{E}} \mathrm{X}$

Printed by LiU-Tryck, Linköping 2019 


\section{POPULÄRVETENSKAPLIG SAMMANFATTNING}

Ordet inflammation kommer från latinets inflammare som betyder "att tända eld". Detta är en talande beskrivning av en process som kan vara ändamålsenlig men också farlig. Inflammation är ändamålsenlig då den neutraliserar sjukdomsalstrande mikroorganismer och hindrar oss från att utföra beteenden som skulle försvåra återhämtning. Den är däremot farlig då den blir kronisk eller överdrivet stark och påverkar fysisk såväl som psykisk hälsa negativt. Den inflammatoriska processen regleras genom ett intrikat samspel mellan immunsystemet och nervsystemet. Signaler från immunsystemet når vår hjärna och påverkar vårt humör och vår inställning till omvärlden så att vi exempelvis hellre stannar i sängen än umgås med vänner. Signalerna utlöser också fysiologiska svar som feber. Störningar i kommunikationen mellan immun- och nervsystemet kan få allvarliga konsekvenser och förståelse av denna kommunikation har potential att leda till nya strategier för att lindra symptom hos människor som drabbats av inflammatoriska sjukdomar.

Den första frågan jag angriper i min avhandling är hur inflammatorisk smärta leder till ett mentalt tillstånd av lidande. Tänk dig att man kunde förvandla smärta till något man känner på samma neutrala sätt som många andra sinnesförnimmelser. Även om vår forskning inte möjliggör något sådant har våra resultat identifierat mekanismer som kan tänkas användas som framtida läkemedelsmål för smärtstillande mediciner. Genom att använda genetiskt modifierade möss visade vi att obehaget, eller lidandet, som inflammatorisk smärta ger upphov till utlöses av en molekyl som heter prostaglandin E2 (PGE2). PGE2 tillverkades i neurala celler av enzymet COX-2. PGE2-bildning kan blockeras av vanliga smärtoch inflammations-dämpande läkemedel, vilka också dämpar de sensoriska aspekterna av smärta. Våra resultat visar att obehags- eller lidande-komponenten i smärtan utlöses av att PGE2 binder till EP3-receptorer på nervceller som frisätter serotonin i framhjärnan. Denna mekanism påverkar dock inte förmågan att lokalisera ett smärtsamt stimulus.

I det andra arbetet studerade vi en nervcellspopulation som på senare tid beskrivits som en viktig hot-detektor i hjärnan. Dessa nervceller finns i hjärnstammens parabrachiala kärna och använder neuropeptiden calcitonin gene-related peptide (CGRP) som signalsubstans. CGRP-cellerna aktiveras av olika typer av faror så som smärta och systemisk inflammation. De CGRP-uttryckande parabrachiala cellerna har visats vara viktiga för inflammationsutlöst aptitförlust, smakaversion och undvikandesvar gentemot smärta. Vi undersökte huruvida CGRP är viktigt för nervcellernas alarmfunktion eller om cellernas andra signalsubstanser räcker för att få fram budskapet. Våra resultat visar att nervcellsgruppens funktion som hot-detektor fungerar väl även utan CGRP.

I det tredje arbetet studerade vi effekterna av stress på inflammationssvaret i musungar. Under barndomstiden genomgår både immun- och nervsystem snabb utveckling och är därmed känsliga för störningar. Följaktligen ökar traumatiska händelser i barndomen risken för både psykiska och inflammatoriska sjukdomar senare i livet. Långtidseffekterna av stress under barndomen är relativt välstuderade men man vet mycket lite om vilka effekter stressen har under barndomen. Vi studerade hur det inflammatoriska svaret i musungar påverkades av att de separerades från sin moder. I den tidiga fasen av immunsvaret sågs en svag dämpning av immunsvaret men efter ett tag övergick denna i en förstärkning av den inflammatoriska signaleringen och av stresshormonsvaret. Den förändring i inflammationsutlöst stresshormonfrisättning och vissa av förändringarna i inflammatorisk signalering som utlöstes av att ungarna separerades från honan kunde utsläckas genom att ungarna fick tillgång till ett varmt och mjukt föremål som ersättning för honan. Vår studie stödjer tanken om att fysisk kontakt är viktig under den tidiga uppväxten.

Sammanfattningsvis bidrar denna avhandling med tre bitar till det komplicerade pussel som kommunikationen mellan immunsystem och hjärna utgör. 


\section{POPULAR SUMMARY}

Inflammation (from the Latin inflammare, to set on fire) is a very accurate term to describe a process which can be very useful, but also extremely dangerous when left unattended. Useful - as inflammatory processes neutralize pathogens and prevent behaviours slowing down recovery. Dangerous - as prolonged or overly strong inflammation has adverse effects on both physical and mental health. The control of inflammatory processes is maintained by complex interactions between the immune and nervous systems: signals from the immune cells reach the brain and change our mindset (so we prefer to stay in bed instead of hanging out with friends) and physiology (and we get fever), while the nervous system dampens or enhances the immune response. Disturbances in this communication can have severe effects and understanding the immune-to-brain and brain-to-immune interactions can help to fight with detrimental symptoms experienced by people suffering from inflammatory diseases.

The first question about immune-to-brain signalling my thesis tries to answer is how inflammatory pain produces mental suffering. Imagine one could feel pain as any other sensory experience, without the unpleasantness it creates. Although we are far from achieving that, our research points at the targets for potential interventions. Using transgenic mouse models, we showed that the negative feelings induced by pain are mediated by a substance called prostaglandin E2 (PGE2), produced in neural cells by an enzyme COX-2. Production of PGE2 can be blocked by popular anti-inflammatory drugs, which also reduce the sensory experience of pain. However, our research shows that PGE2 binding to EP3 receptors on neurons releasing serotonin to the forebrain is responsible for the induction of negative mood, without affecting the ability to feel the location of pain.

In the second paper, we studied a neuronal population recently described as general alarm generators. These neurons are located deep in the brain in a region called the parabrachial nucleus and produce a small molecule, Calcitonin Gene-Related Peptide (CGRP). CGRPsynthesising neurons respond to variety of threats, including activation of the immune system and pain. Other groups demonstrated that CGRP-producing neurons are important for loss of appetite during inflammation, creating disgust towards food which made us sick and escaping from the source of pain. We wanted to know if the neurons in the parabrachial nucleus use CGRP to produce normal responses to inflammation and pain. Our results show that inflammation- and pain-related responses are induced by CGRP-producing neurons through other signalling molecules than CGRP. Hence, blocking CGRP signalling might not be an efficient strategy to prevent inflammation-induced loss of appetite.

The third paper focuses on the effects of stress on inflammatory responses in early life. During that period, both the immune and the nervous system undergo fast development, hence are sensitive to disturbances. Indeed, traumatic experiences during childhood increase the risk for developing psychiatric and inflammatory diseases in adulthood. Many studies have focused on long-term consequences of early life stress but very little is known about its effects during childhood. We investigated how the immune response of pups was affected by separation from their dam, i.e. maternal separation. At the very early stage of inflammation, separated pups showed lower immune response than pups staying with their mothers. As the inflammation progressed, stressed pups produced more pro-inflammatory factors and more stress hormone than pups receiving maternal care. Interestingly, placing the separated pups close to a warm and soft object normalized levels of some of the pro-inflammatory molecules and stress hormone. Our study supports the notion of the importance of close physical contact with a caregiver during childhood.

To summarise, research described in this thesis adds three missing pieces to the complicated puzzle of communication between the immune and nervous systems during inflammation. 


\begin{abstract}
Reciprocal interactions between the nervous and immune systems have gained a lot of attention in the last two decades, especially after demonstrating that cytokine immunotherapies can induce depression and after describing the inflammatory reflex. A lot of effort has been dedicated to understanding how the signals from the immune system reach the brain and vice versa, and on their role in health and disease. However, it is not well-known which of the brain circuits, receptors and signalling molecules give rise to behavioural and affective changes induced by inflammation, such as reduced food intake and induction of negative mood. Moreover, although it is well established that early life stress leads to an increased risk of developing inflammatory diseases in adulthood, the acute effects of stress on the inflammatory response in childhood are not well described. Using mouse models of systemic and local inflammation, I studied (1) how inflammatory pain elicits negative affect, (2) if CGRP $\alpha$ is necessary for parabrachial-amygdaloid pathway-mediated behaviours associated with pain and inflammation, and finally, (3) what are the effects of stress on the inflammatory process during early life. The results indicate that (1) the negative affect of inflammatory pain is triggered by inhibition of serotonergic neurons of the dorsal raphe nucleus, as a result of prostaglandin E2 binding to EP3 receptors; (2) CGRP $\alpha$ is dispensable for most pain- and inflammation-related protective behaviours; (3) acute stress potentiates the pro-inflammatory cytokine expression after an inflammatory challenge in mouse pups. The phenomena studied here can contribute to understanding how immune system activation induces changes in mood and behaviour common for inflammation and depression.
\end{abstract}





\section{Acknowledgments}

I would like to thank all the people who contributed to this thesis, through scientific, technical, and mental support, especially:

David Engblom, for your calmness, having the door to your office always open and for helping me to become a more self-confident person.

Kiseko Shionoya, for your sense of humour, strong spirit and the enormous amount of support and knowledge I have received from you.

Anders Blomqvist, for everything I have learned from you on our lab meetings.

Annika Thorsell, for listening when I needed it.

Jan Rodriguez Parkitna, for believing in me.

Fredrik, Andy, for our time in The Cave and for teaching me that although science is important, being happy is essential.

Silvia, for not letting me panic.

Joost, it was very important for me that I knew that I could always ask you for advice, I wish you came to our group earlier!

Maarit, for all the help, especially with things I couldn't reach without a stool!

Johan, only you realise how chaotic I am, so thanks for not telling anyone.

Our students, especially Isabelle and Susanne, for making experiments much more fun.

Anna A., for your miraculous ability to always cheer me up. Even without using sugar!

Eric, for the special kind of understanding.

Estelle, Esi and Filip for making work more fun.

Gaëlle, Li, Kanat, for the pleasant atmosphere we have in our office.

Elahe, for all your help through the years and for teaching me immunohistochemistry.

Daniel, Anna N., Sofie, Nina, for demonstrating that finishing $\mathrm{PhD}$ is possible!

Daniel N., for patiently answering my questions about Principal Component Analysis.

Aki and Takashi, for intercontinental support. 
Lovisa Ö., do you remember that chocolate you gave me when I was very sad? I do.

Niki, I would not finish this $\mathrm{PhD}$ without you. I mean it.

Claudio, you are the best.

Karolina, for always being close.

Kate, for helping me with things I was afraid of.

Ewka, Nina, Ela, Wielka, Konrad, for making me feel like I always have something to go back to, no matter what.

Kenan, Anders, Gustav, Rebecca, Johan and Petros, for being there for me when I needed to vent my lab frustrations. \#nodrama

Mamo, Tato, dziękuję za mikroskop na biurku, formalinę w piwnicy, glony z Mleczki w bagażniku i za to, że zawsze mogę na Was liczyć. 


\section{Contents}

Abstract iii

Acknowledgments viii

Contents ix

List of Figures xii

Abbreviations xiii

List of Papers XV

1 Background 1

1.1 Cvtokines and prostaglandins $\ldots \ldots \ldots \ldots \ldots \ldots$

1.2 Immune-to-brain signalling $\ldots \ldots \ldots \ldots \ldots \ldots$

Local inflammation . . . . . . . . . . . . . . . . . . 4

Pain pathwavs ...................... . . 4

The sensory and affective components of pain ...... 4

The parabrachial-amvgdaloid pathwav in pain processing 5

Systemic inflammation and the sickness syndrome . . . . . . 5

Inflammation-induced anorexia .............. 5

The parabrachial-amygdaloid pathway in food intake

control ................ 6

1.3 Brain-to-immune signalling . . . . . . . . . . . . . . 6

Modulation of immune response through the autonomous ner-

vous svstem ...................... 7

Modulation of immune response through the HPA-axis . . . . 7

2 Methods 9

2.1 Mouse models . . . . . . . . . . . . . . . . . . . . . . . 9 9

2.2 Cell-type specific manipulations: Cre/loxP system . . . . . . . 9

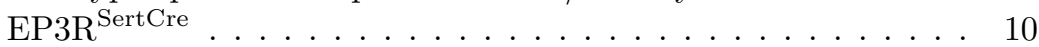

Vector-based manipulations . . . . . . . . . . . . . . 10

Chemogenetics ..................... 11 
2.3 Global gene deletions: CGRP $\alpha$-KO . . . . . . . . . . . 12

2.4 Inflammatory pain model: Formalin injections . . . . . . . . 13

Assessing the affective component of pain: Conditioned Place Aversion ........................ 13

Assessing the sensory component of pain: Nociceptive scoring . 14

2.5 Systemic inflammation model: Intraperitoneal lipopolysaccharide injections . . . . . . . . . . . . . . . . . . . . . . . . 14

LPS-induced anorexia ... . . . . . . . . . . . . . . . . . 14

Conditioned Taste Avoidance . . . . . . . . . . . . . . . . . . . 15

Inflammatory challenge in presence or absence of the dam . . 15

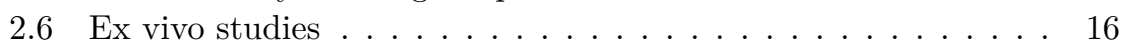

Immunofluorescence . . . . . . . . . . . . . . . . 16

Quantitative Polvmerase Chain Reaction (qPCR) . . . . . . . 16

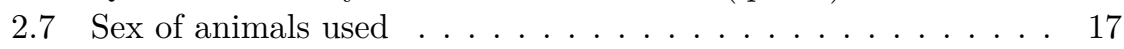

2.8 Statistical analysis $\ldots \ldots \ldots \ldots \ldots \ldots \ldots \ldots$

\begin{tabular}{lll}
\hline 3 Aim and significance & 19
\end{tabular}

4 Results and discussion 21

4.1 Paper I: Prostaglandin-mediated inhibition of serotonin signal-

ing controls the affective component of inflammatory pain . .. . 21

Activation of EP3 receptors by PGE2 of neural origin influences the affective component of inflammatory pain ...... 21

The EP3 receptors mediating the affective component of inflammatory pain are located on serotonergic cells .... . 22

Inhibition of the serotonergic neurons of the dorsal raphe mediates the affective component of pain ........... 22

4.2 Paper II: Calcitonin gene related peptide $\alpha$ is dispensable for many danger-related motivational responses . . . . . . . . . . 24

CGRP $\alpha$ is absent in the projections to the central amygdala in CGRP $\alpha-\mathrm{KO}$ mice .................... 24

CGRP signaling is not necessary for inflammation induced anorexia and conditioned taste aversion ......... . . 24

CGRP signaling is not necessary for pain-related behaviors . . 25

4.3 Paper III: Acute maternal separation potentiates the gene expression and corticosterone response induced by inflammation. 26

Maternal separation slightly attenuates proinflammatory gene induction one hour after inflammatory challenge without affecting CORT levels ............... 26

Maternal separation potentiates proinflammatory gene induction and CORT response three hours after inflammatory challenge

A warm and soft object attenuates some of the effects of sepa-

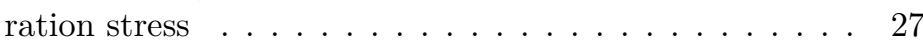


Corticosterone levels correlate with IL-6, Ccl2 and hepatic IL-

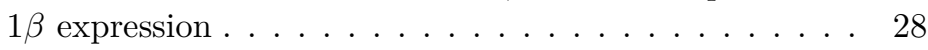

5 Conclusions

5.1 Paper I: Prostaglandin-mediated inhibition of serotonin signal-

ing controls the affective component of inflammatory pain . . . 29

5.2 Paper II: Calcitonin gene related peptide $\alpha$ is dispensable for many danger-related motivational responses . . . . . . . . . 29

5.3 Paper III: Acute maternal separation potentiates the gene expression and corticosterone response induced by inflammation. 30

Bibliography 31

\begin{tabular}{ll}
\hline Paper I & 45
\end{tabular}

\begin{tabular}{ll}
\hline Paper II & 61
\end{tabular}

\begin{tabular}{ll}
\hline Paper III & 75
\end{tabular} 


\section{List of Figures}

1.1 Prostanoid synthesis pathway. Phospholipases hydrolise membrane phospholipids into arachidonic acid. Arachidonic acid is converted by cyclooxygenases Cox-1 or Cox-2 into Prostaglandin H2 (PGH2), through Prostaglandin G2 (PGG2). Terminal isomerases convert PGH2 into prostanoids. mPGES - Microsomal prostaglandin E synthase, cPGES - Cytosolic prostaglandin E synthase, PGF2 - Prostaglandin F2, PGD2 - Prostaglandin D2. Ovals

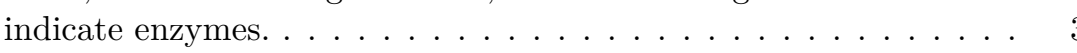

4.1 Suggested mechanism of the affective component of inflammatory pain: 1. PGE2 is produced in neural cells through Cox-2. 2. PGE2 binds to EP3 receptors on serotonergic cells of the DRN. 3. EP3 receptor activation leads to inhibition of serotonergic

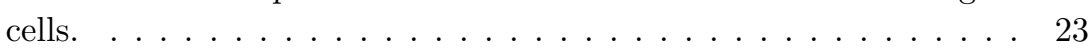




\section{Abbreviations}

5-HT 5-hydroxytryptamine, i.e. Serotonin

AAV Adeno-Associated Viral Vector

ACC Anterior Cingulate Cortex

AgRP Agouti-Related Protein

ANS Autonomous Nervous System

BBB Blood-Brain-Barrier

Ccl2 C-C Motif Chemokine Ligand 2

CGRP Calcitonin Gene-Related Peptide

CNO Clozapine- $N$-Oxide

CNS Central Nervous System

CORT Corticosterone

COX Cyclooxygenase

CPA Conditioned Place Aversion

CTA Conditioned Taste Aversion

Cxcl10 C-X-C Motif Chemokine 10

DIO Double-Floxed Inverted Open Reading Frame

DREADDs Designer Receptors Exclusively Activated by Designer Drugs

DRN Dorsal Raphé Nucleus

EP3R Prostaglandin E2 Receptor Subtype 3

GFP Green Fluorescent Protein

hM3Dq Human M3 Muscarinic DREADD Receptor Coupled to Gq

hM4Di Human M3 Muscarinic DREADD Receptor Coupled to Gi 


$\begin{aligned} \text { HPA-axis } & \text { Hypothalamic-Pituitary-Adrenal-Axis } \\ \text { IL-1 } \beta & \text { Interleukin-1 } \beta \\ \text { IL-6 } & \text { Interleukin-6 } \\ \text { i.p. } & \text { Intraperitoneal } \\ \text { IP3 } & \text { Inositol Trisphosphate } \\ \text { KO } & \text { Knock-Out } \\ \text { LPS } & \text { Lipopolysaccharide } \\ \text { mPGES-1 } & \text { Microsomal Prostaglandin E Synthase-1 } \\ \text { PBN } & \text { Parabrachial Nucleus } \\ \text { PN } & \text { Postnatal } \\ \text { qPCR } & \text { Quantitative Polymerase Chain Reaction } \\ \text { SERT } & \text { Serotonin Transporter } \\ \text { SHRP } & \text { Stress Hyporesponsive Period } \\ \text { TNF } \alpha & \text { Tumor Necrosis Factor } \alpha \\ \text { WSOb } & \text { Warm and Soft Object }\end{aligned}$




\section{List of Papers}

Paper I

Anand Kumar Singh, Joanna Zajdel, Elahe Mirrasekhian, Nader Almoosawi, Isabell Frisch, Anna M Klawonn, Maarit Jaarola, Michael Fritz, and David Engblom (2017). "Prostaglandin-mediated inhibition of serotonin signaling controls the affective component of inflammatory pain". In: J Clin Invest 127.4, pp. 1370-1374

Paper II Joanna Zajdel, Johan Sköld, Julia Levinsson, Redoy Ullah, Marit Jaarola, Anand Kumar Singh, and David Engblom (2019). "Calcitonin gene related peptide alpha is dispensable for many danger-related motivational responses". In: Manuscript

Paper III Joanna Zajdel, Adriano Zager, Anders Blomqvist, David Engblom, and Kiseko Shionoya (2019). "Acute maternal separation potentiates the gene expression and corticosterone response induced by inflammation". In: Brain Behav Immun 77, pp. 141-149 



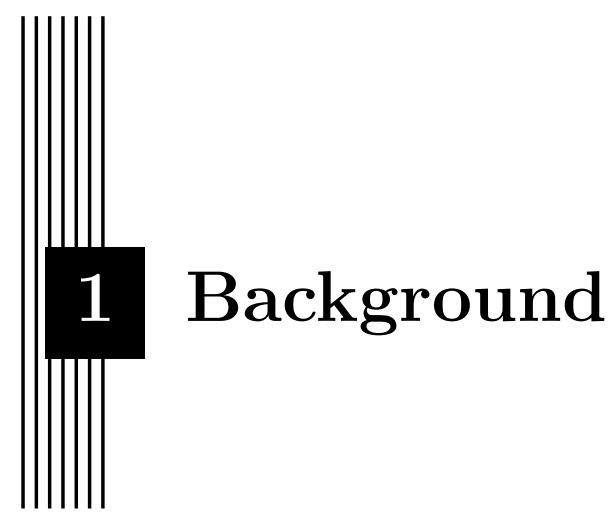

A crucial part of staying alive is detecting, neutralizing, and learning to avoid potential threats. Evolution has equipped us with two systems specialised in protection from danger: the immune and nervous systems. Very often the immune and nervous systems respond to the same threat, but on different levels. For example, if the nervous system fails to stop us from eating rotten food, the immune system can act as the second line of defence and protect us from the consumed pathogens. The immune system can also sensitize the nervous system, so the next time we approach the same food even its smell will make us nauseated.

The phenomenon described above, known as conditioned taste avoidance, is an example of immune-to-brain signalling. More generally, immune-to-brain signalling gained attention in the 1980s, when Besedovski reported that peripheral injections of interleukin-1 (Il-1), a signalling molecule released by immune cells during inflammation, activates the hypothalamic-pituitary-adrenal (HPA)-axis (Besedovsky et al. 1986). The interactions in the other direction, i.e. brain-to-immune, had been studied since the $1950 \mathrm{~s}$, when stress was shown to influence the course of various diseases (Dantzer 2018).

Since then, we have gained knowledge about the possible routes of communication between the nervous and the immune system and identified more processes regulated by those interactions. However, the exact pathways of signal transduction are still unknown for many processes regulated by neuroimmune interactions. In this thesis, I describe my findings on how inflammatory pain elicits negative affect (paper I), the role of calcitonin gene-related peptide $\alpha$ 
$(\mathrm{CGRP} \alpha)$ in pain-related behaviours and inflammation-induced reduction in food intake (paper II), and on the acute effects of stress on inflammation in early life (paper III).

\subsection{Cytokines and prostaglandins}

The first step to understanding the communication between the immune and nervous systems are the signalling molecules, such as cytokines and prostaglandins.

Cytokines are small secretory proteins, which can exert both pro- and antiinflammatory actions through auto-, para- and endocrine signalling. As most cytokines have pleiotropic effects, they can orchestrate the immune response of the whole body.

During inflammation, cytokines induce production of another type of signalling molecules, called prostaglandins. Prostaglandins are synthesised from membrane phospholipids through a series of enzymatic reactions (figure 1.1). Cyclooxygenase-2 (COX-2) and microsomal prostaglandin E synthase-1 (mPGES-1) are enzymes involved in prostaglandin synthesis in response to inflammation, as their levels are strongly up-regulated by pro-inflammatory cytokines (Murakami et al. 2000). The final product of the reaction mediated by mPGES-1 is prostaglandin E2 (PGE2), a critical mediator of many inflammatory processes, including hyperalgesia and fever induction (Blomqvist et al. 2018). However, enzymes that are constitutively present in cells can also play a role in the initial stage of inflammation, as it was demonstrated for the involvement of COX-1 derived PGE2 in the early phase of corticosterone (CORT) release (Elander et al. 2009). PGE2 actions are mediated by 4 types of receptors (EP1-EP4), with a very broad expression pattern (Sugimoto et al. 2007).

\subsection{Immune-to-brain signalling}

The transfer of signals from the immune system to the brain is much more challenging than to other organs, as the central nervous system (CNS) is partially isolated by the blood-brain-barrier (BBB). In normal conditions the BBB cannot be permeated by neither immune cells nor most of their mediators. This presents a question: how does the information from the immune system reach the brain? Several possibilities have been proposed: (1) cytokine leakage through circumventricular organs with permeable, fenestrated capillaries; (2) activation of endothelial cells and perivascular macrophages in the walls of the cerebral vasculature, and release of inflammatory mediators into the brain parenchyma; (3) active transport of cytokines by transporter proteins; (4) through receptors on afferent nerve fibres; and finally (5) through recruitment of immune cells from the periphery (Blomqvist et al. 2018; Ha- 


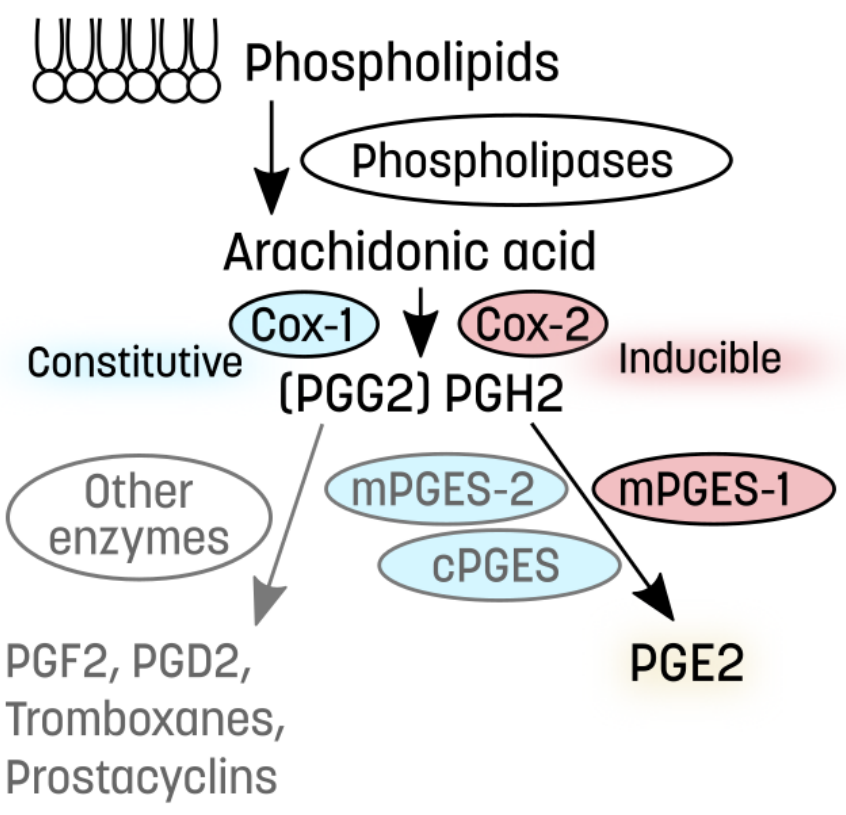

Figure 1.1: Prostanoid synthesis pathway. Phospholipases hydrolise membrane phospholipids into arachidonic acid. Arachidonic acid is converted by cyclooxygenases Cox-1 or Cox-2 into Prostaglandin H2 (PGH2), through Prostaglandin G2 (PGG2). Terminal isomerases convert PGH2 into prostanoids. mPGES - Microsomal prostaglandin E synthase, cPGES - Cytosolic prostaglandin E synthase, PGF2 - Prostaglandin F2, PGD2 Prostaglandin D2. Ovals indicate enzymes.

roon et al. 2012). Different signalling routes are necessary to trigger different responses of the CNS (Dantzer 2018). For example, both social withdrawal and fever can be elicited by the same cytokine, IL- $1 \beta$, but social withdrawal is mediated through vagal nerve signalling (Konsman et al. 2000), while fever by activation of endothelial cells (Blomqvist et al. 2018).

Besides the possible routes of immune-to-brain signalling, another relevant question is which brain circuits/receptors/signalling molecules are responsible for producing physiological and behavioural changes in response to the immune system activation. For some phenomena, such as for fever, these mechanisms are relatively well-described (Blomqvist et al. 2018), but less is known about e.g. inflammation-induced anorexia, negative mood or social withdrawal. 


\section{Local inflammation}

As mentioned before, the immune system can detect abnormalities in the tissue, such as pathogens or cellular damage, and act to neutralize them. The process is initiated by the resident immune cells, activated by molecules present in pathogens (e.g. bacterial lipopolysaccharide, LPS), or by molecules leaking from damaged cells (e.g ATP or oxidized proteins). Activated immune cells release inflammatory mediators, which leads to vasodilation, recruitment of more immune cells and development of inflammatory pain. Pain can be elicited by inflammatory mediators either directly, through binding to receptors on primary sensory neurons or indirectly, through enhancing pain transduction (Ji et al. 2016).

\section{Pain pathways}

The sensation of pain can be evoked by activation of small-diameter sensory neurons by thermal, mechanical and chemical stimuli. The sensory neurons project to the lamina I of the dorsal horn of the spinal cord. Cells in lamina I transfer the pain signal to brainstem structures, including the parabrachial nucleus (PBN) (Cechetto et al. 1985), a structure crucial for maintaining homeostasis (Palmiter 2018). The PBN sends projections to the periaqueductal grey and the hypothalamus, regions regulating autonomic, neuroendocrine and behavioural activity. Other structures receiving pain signals from the PBN include the amygdala (direct projections from the PBN) (Richard et al. 2005), the insula and the anterior cingulate cortex (ACC) (both through thalamic nuclei) (Craig 2003). An additional pathway, projecting directly from lamina I to the thalamus and from the thalamus to interoceptive cortex, was described in primates, but it is considered rudimentary in other mammals (Craig 2003).

\section{The sensory and affective components of pain}

The main function of pain is to modify behaviour in order to minimize and avoid tissue damage. In the short term this could be achieved by a simple sensory reflex. However, in order to protect the injured area and to avoid the source of pain in the future, tissue damage needs not only to be detected and localised, but also to create a perception of unpleasantness and distress. Studies indicate that different brain regions are involved in processing the sensory component of pain (the ability to assess location and modality of pain), and its affective component (the negative feelings pain evokes) (Craig 2003; Price 2000). The unpleasantness of pain is most likely mediated by the ACC (Johansen et al. 2001; Price 2000; Rainville et al. 1997) and the amygdala (Corder et al. 2019; S. Han et al. 2015). Understanding the biological link between pain and negative affect is particularly important, as pain and depression have high comorbidity: $\sim 50 \%$ of patients with depression experience 
pain (Katona et al. 2005) and $~ 50 \%$ of patients in pain clinics are depressed (Bair et al. 2003).

\section{The parabrachial-amygdaloid pathway in pain processing}

As mentioned earlier, the $\mathrm{PBN}$ receives inputs conveying information about the internal state of the body, including lamina I neurons transferring pain signals (Cechetto et al. 1985). Pain of different modalities activates neurons expressing $\mathrm{CGRP} \alpha$ in the lateral subdivision of $\mathrm{PBN}$ ( $\mathrm{CGRP}^{\mathrm{PBN}}$ neurons) (Campos et al. 2018; S. Han et al. 2015). Moreover, silencing CGRPPBN neurons blocks defensive responses to pain (S. Han et al. 2015). CGRPPBN neurons send projections to the capsular subdivision of the central amygdala (CeC) (Carter, Soden, et al. 2013; Schwaber et al. 1988), a structure important for linking pain with emotions (Neugebauer 2015). Stimulation of the $\mathrm{CGRP}^{\mathrm{PBN}}$ to $\mathrm{CeC}$ projections produces defensive responses (S. Han et al. 2015) and $\mathrm{CGRP}^{\mathrm{PBN}}$ to $\mathrm{CeC}$ synapses exhibit long-term potentiation in inflammatory pain models (Sugimura et al. 2016). The release of CGRP, a 37amino acid peptide, was shown to be necessary for $\mathrm{CGRP}^{\mathrm{PBN}}-\mathrm{CeC}$ synaptic potentiation and development of hyperalgesia after formalin injection (J. S. Han et al. 2005; Shinohara et al. 2017).

\section{Systemic inflammation and the sickness syndrome}

The inflammatory mediators produced locally in injured or infected tissue can trigger systemic reactions, involving distant organs such as liver or brain. During systemic inflammation, the brain produces a set of responses, including fever, corticosteroid secretion, lethargy, feelings of discomfort/malaise, social withdrawal and decreased food intake, collectively known as the sickness syndrome (Saper et al. 2012). Similarly to pain, the sickness-induced changes in behaviour can be viewed as a shift in motivation, increasing chances of survival both on individual level (e.g. fatigue) and on a group level (e.g. social withdrawal), yet sensitive to other internal and external factors (Konsman 2016).

\section{Inflammation-induced anorexia}

Decrease in appetite and food intake is a common symptom of inflammation among many species (Hart 1988). Intuitively, it may seem disadvantageous to limit caloric intake during fever, which has high energetic cost. Nevertheless, being less motivated to search for food could reduce the spread of the disease, and diminished hunger could prevent the group from wasting resources on a sick individual. However, inflammation-induced anorexia can also be beneficial on the individual level. Force-feeding to normal caloric intake was shown to decrease survival during bacterial infection (Murray et al. 1979), and prestarving to increase the survival rate (Wing et al. 1980). While hypophagia is 
protective during acute inflammation, it not beneficial during chronic conditions. Decreased appetite, contributing to involuntary weight loss, is common in diseases such as AIDS or chronic obstructive pulmonary disease and has a negative impact on quality of life and survival (Dwarkasing et al. 2016).

\section{The parabrachial-amygdaloid pathway in food intake control}

The parabrachial-amygdaloid pathway, mentioned before in the context of pain, is also involved in regulation of food intake. The PBN receives sensory input from the vagal nerve through glutamatergic projection from the nucleus of the solitary tract (NTS) (Norgren et al. 1971; Wu et al. 2012). Activation of $\mathrm{CGRP}^{\mathrm{PBN}}$ neurons is observed after administration of aversive substances which suppress feeding, such as $\mathrm{LiCl}$ or inflammation-inducing LPS (Campos et al. 2018; Paues et al. 2001), and satiety hormones (Carter, Soden, et al. 2013). The counterbalance for glutamatergic inputs onto PBN comes from the arcuate nucleus, more specifically, from GABAergic Agouti-Related Protein (AgRP)-expressing neurons (Carter, Soden, et al. 2013). Removing the inhibitory input on the PBN was shown to cause starvation (Wu et al. 2012), as activation of CGRP ${ }^{\mathrm{PBN}}$ neurons severely inhibits food intake (Carter, Soden, et al. 2013). CGRP ${ }^{\mathrm{PBN}}$ neurons are involved in acquisition and expression of conditioned taste aversion (CTA), i.e. associating a taste with a feeling of malaise and avoiding the same taste in future (Carter, S. Han, et al. 2015). Pairing stimulation of $\mathrm{CGRP}^{\mathrm{PBN}}$ to $\mathrm{CeA}$ projections (i.e. the same projections which stimulations triggers nocifensive behaviours) with a novel taste is sufficient to induce CTA (J. Y. Chen et al. 2018).

Interestingly, as a common node for feeding and pain signals, CGRP ${ }^{\mathrm{PBN}}$ neurons mediate hunger-induced suppression of nociceptive behaviors triggered by inflammatory pain (Alhadeff, $\mathrm{Su}$, et al. 2018).

To conclude, peripheral inflammation sends signals to the brain centres regulating mood and motivational states, and promotes behaviours conducting to recovery and healing. This shift in motivation is beneficial in the short term, but can diminish the quality of life during chronic inflammatory conditions.

\subsection{Brain-to-immune signalling}

As mentioned before, the interactions between the nervous and immune systems are reciprocal. The modulation of the immune system by emotional states has been proposed to be mediated by two main mechanisms: through the autonomous nervous system (ANS) and through the HPA-axis. 


\section{Modulation of immune response through the autonomous nervous system}

The regulation of immune system by the ANS is well-studied for its sympathetic branch, while the involvement of the parasympathetic remains more unclear. The lymphoid tissue is predominantly innervated by the sympathetic part, and recently it has been reported that the activation of the reward system can enhance immune response to bacterial infection and tumors through the sympathetic nervous system (Ben-Shaanan, Azulay-Debby, et al. 2016; Ben-Shaanan, Schiller, et al. 2018). The parasympathetic branch is the efferent part of the inflammatory reflex, acting as a brake on cytokine production (Tracey 2002). The vagal nerve and cholinergic signaling are necessary for this effect, but the exact mechanism of the inflammatory reflex is still unknown (Dantzer 2018).

\section{Modulation of immune response through the HPA-axis}

Another well-known mechanism through which the nervous system controls the immune system is suppression of immune functions by the HPA-axis activation. In response to different kinds of stressors, the paraventricular nucleus secretes corticotropin releasing hormone $(\mathrm{CRH})$. $\mathrm{CRH}$ secretion into the pituitary gland leads to release of adrenocorticotropin (ACTH). Increase in $\mathrm{ACTH}$ in circulation results in glucocorticoids production by the adrenal cortex (Bellavance et al. 2014). Glucocorticoids (mainly corticosterone, CORT, in mice and cortisol in humans) exert their effects through transcriptional repression of transcription factors, such as NF- $\kappa \mathrm{B}$ or AP-1 (Sorrells et al. 2009). As a result, expression of genes coding for inflammatory mediators is downregulated.

Interestingly, in some conditions glucocorticoids can enhance immune responses (Sorrells et al. 2009), e.g. adult rats stressed $24 \mathrm{~h}$ before inflammatory challenge show sensitised immune response (Johnson et al. 2002). In the CNS, this effect was proposed to be mediated through glucocorticoids acting on microglia and triggering a signalling pathway leading to activation of caspase-1 and more rapid production of Il-1 $\beta$ (Frank et al. 2015).

The phenomena described above were observed in adult animals and are not necessarily identical in young ones, because of differences in functioning of the HPA-axis. Stress and high glucocorticoid levels can have damaging effects on developing organisms, which are known to be more sensitive to disturbance (Sapolsky et al. 1986). Not surprisingly, there is a period in development, at least in some species, when young animals show low basal levels of CORT and dampened glucocorticoid response. This period, so-called stress hyporesponsive period (SHRP), is well-studied in mice and rats, and lasts approximately from 2-4 postnatal (PN) day to day 15 (Sapolsky et al. 1986). There is accumulating evidence that SHRP is also present in humans (Gunnar et al. 2002). 
Starting around the fourth month of life, infants gradually develop resilience to stressful events, which can be observed as a reduction in cortisol release in response to injections and physical examination. Interestingly, responsiveness to stress shows inverted correlation with the levels of care provided by the caretaker. The same phenomenon was observed in rodents, where prolonged absence of a dam 'unlocks' the responsiveness to stressors (Stanton, Gutierrez, et al. 1988).

What makes the interactions between stress and the developing immune system even more interesting, are observations that early life stress has long lasting effects on the immune system. Maternal separation of mouse pups has been demonstrated to potentiate immune response in adulthood (Avitsur et al. 2009). A similar phenomenon is observed in humans, as child abuse increases risk of developing inflammatory diseases in adulthood (Danese et al. 2009; Dube et al. 2009).

In summary, the nervous system is mostly involved in tuning the immune response to the current environmental conditions and acts as a brake on activated immune response. 


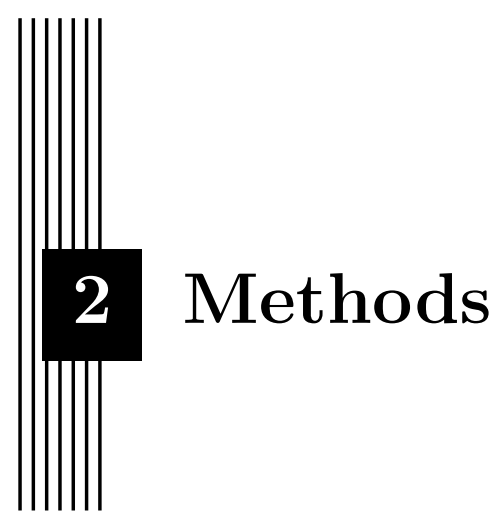

\subsection{Mouse models}

The studies described here have been performed on mice. Working with any animal model implies ethical considerations, but it is the only currently available way to study a complete biological system in its full range of reactions. When the purpose of a study is to understand how changes on molecular level influence behaviour, animal models are very often irreplaceable. Precise manipulations on molecular level are relatively easy to perform on mice, due to the availability of genetic engineering methods. Although the recent development of the CRISPR/Cas9 system has increased the number of species accessible for genome editing ( $\mathrm{Hsu}$ et al. 2014), mouse models might remain popular because they are well-studied and standardised.

\subsection{Cell-type specific manipulations: Cre/loxP system}

As the brain is a mosaic of many cell types, understanding its function requires cell-type specific techniques. Many of them utilize expression of a transgene driven by a promoter active exclusively in a particular cell type. In paper I, we utilized the Cre/loxP system (Sternberg et al. 1981) in order to selectively manipulate serotonergic neurons. The system consists of two elements: Cre recombinase, determining the selectivity and efficiency of a manipulation, and short DNA sequences, called lox. The nature of a manipulation depends on the orientation of two lox sites and on the DNA sequence between them. The 
DNA between two lox sites aligned in the same direction is excised, while DNA between two lox sites facing each other is inverted by Cre (Branda et al. 2004).

Both elements of Cre/loxP system can be introduced into muse genome either by methods used for generation of transgenic lines or through local injections of viral vectors.

\section{EP3R $R^{\text {SertCre }}$}

To create animals without Prostaglandin E2 Receptors Subtype 3 (EP3Rs) on serotonergic neurons, we crossed transgenic mice carrying Cre under control of serotonin transporter (SertCre) with mice from so-called Ptger3 flox line. Animals from Ptger3 flox line have the gene encoding EP3R flanked by loxP sites aligned in the same direction. In cells where Cre expression occurs, Cre mediates excision of the DNA sequence between them, i.e. Ptger3 deletion.

As exogenous transgenes can have low or ectopic expression, we confirmed that Cre is present exclusively in serotonergic neurons by immunohistochemistry. The efficiency of recombination was tested by measuring mRNA levels of the targeted gene.

A similar approach was used to generate mice with cell-specific deletions of the Ptgs2 gene, encoding Cox-2.

\section{Vector-based manipulations}

As the Sert promoter driving Cre expression is active in all serotonergic cells, removing EP3R only from one serotonergic nucleus requires a different approach. For local deletion of EP3Rs in the Dorsal Raphé Nucleus (DRN) we injected mice from Ptger3 flox line with AAV5-hSyn-Cre, i.e. AdenoAssociated Viral Vectors transducing all types of neurons with a transgene encoding Cre. AAVs were chosen as the most commonly used viral vectors, as they are considered safe and induce only minimal inflammatory response (Aschauer et al. 2013). Transgene expression was driven by the synapsin promotor, active in all types of neurons, hence in this experiment the deletion of EP3R was not restricted to serotonergic neurons. To my knowledge, there are no strong, short promoters selective to serotonergic neurons. The small size of a promoter is crucial for constructs carried by AAVs, as they have limited capacity.

To confirm that recombination occurred in the DRN, AAV5-hSyn-Cre were mixed with a Cre-dependent vector, AAV5-EF1 $\alpha$-DIO-eYFP. It is worth to note that the term "Cre-dependent vector" is an oversimplification: the "Credependent vector" transduced all types of cells in the injected region, but the transgene remained inactive until it was inverted by Cre to the orientation al- 
lowing for transcription (so-called DIO, Double-Floxed Inverted Open reading frame, also known as FLEx).

In another set of experiments, we injected mice from the SertCre line with Cre-dependent vectors carrying chemogenetic constructs: AAV8-hSynDIO-hM3Dq-mCherry and AAV8-hSyn-DIO-hM4Di-mCherry. In this case, transgene expression was restricted to serotonergic cells in the DRN.

The delivery of the vectors was performed by stereotaxic surgery. The head of the animal was fixed on a stereotaxic frame, to ensure the correct placement of injection. A small hole was drilled in the skull, and the vectors were slowly delivered to the DRN through a thin needle. To control for possible surgery-, vector- or exogenous protein-induced effects, additional groups were injected with AAVs of the same pseudotype, containing transgenes coding fluorescent proteins, but no Designer Receptors Exclusively Activated by Designer Drugs (DREADDs) or Cre.

Behavioural experiments were performed 3 weeks after the surgeries. This time is required not only for mice to recover, but also for efficient expression of DREADDs. After the behavioural experiments, the placement of the injection was validated by immunohistochemical staining. Mice not expressing the transgenes in the DRN were excluded from statistical analysis.

Although viral vectors are very versatile tools, the variability of transgene expression strength and pattern is much higher than in case of using transgenic lines.

\section{Chemogenetics}

Chemogenetics enables activation or inhibition of specific neural populations in freely moving animals and can be used to establish a causal relationship between neuronal activity and behaviour. Changes in neuronal activity can be induced within minutes and the effects of the manipulation last hours (Urban et al. 2015), making it compatible with longer behavioural experiments. The control of specific neuronal populations is achieved through artificial receptors, insensitive to native ligands and lacking basal activity, so-called Designer Receptors Exclusively Activated by Designer Drugs (DREADDs) (Armbruster et al. 2007).

In paper I, we used two most popular types of DREADDs: hM3Dq and hM4Di (Armbruster et al. 2007). Both are modified human muscarinic receptors (M3 and M4), activating the same pathways as the wild-type versions (Urban et al. 2015). The modifications make the receptors insensitive to acetylcholine and sensitive to clozapine- $N$-oxide $(\mathrm{CNO}) /$ clozapine (Armbruster et al. 2007). hM3Dq is linked to Gq protein and its activation leads to an increase in neuronal excitability through phospholipase C (PLC) dependent mechanism (Alexander et al. 2009). PLC cleaves phosphatidylinositol (PIP2) into inositol trisphosphate (IP3) and diacylglycerol (DAG). Depletion of PIP2 leads to closing of KCNQ channels, while IP3 releases calcium from endoplas- 
mic reticulum, both possibly contributing to depolarisation (Alexander et al. 2009; Spangler et al. 2017). Activation of hM4Di, linked to Gi, leads to silencing of neuronal firing through activation of $\mathrm{G}$ protein-coupled inwardly rectifying potassium (GIRK) channels and subsequent hyperpolarisation, but also to suppression of neurotransmitter release, presumably through cAMPdependent modulation of calcium channels or through $\mathrm{G} \beta$ subunits inhibiting the synaptic vesicle fusion machinery (Armbruster et al. 2007; Stachniak et al. 2014).

As DREADDs interact with downstream effector proteins, which may differ from one cell type to another, it is important to check if administration of CNO leads to the desirable effect. The effects of activation of both hM3Dq and hM4Di in serotonergic neurons have been already described in literature (Teissier et al. 2015). Another drawback of DREADDs is that activation of second messenger pathways may not only change the excitability of a neuron, but also have other effects.

The compound used for activation of DREADDs, CNO, in the early years of chemogenetics used to be described as 'pharmalogically inert'. Recently, it has been reported that the effects of systemic CNO injections are in reality mediated through its metabolite, clozapine, since CNO does not efficiently pass the BBB (Gomez et al. 2017). Nevertheless, it had been known that CNO can be converted to clozapine, an atypical antipsychotic. Because of that, we injected the control animals (i.e. animals not expressing DREADDs) with the same dose of $\mathrm{CNO}$ as animals expressing DREADDs. This approach is considered an appropriate control for potential off-target effects of $\mathrm{CNO} /$ clozapine (Mahler et al. 2018).

\subsection{Global gene deletions: $\operatorname{CGRP} \alpha-\mathrm{KO}$}

To study the role of CGRP $\alpha$ we used a transgenic line originally created for ablation of cells expressing Calca, the gene encoding CGRP $\alpha$, described in $\mathrm{McCoy}$ et al. 2012. The line carries a transgene with a floxed STOP cassette, i.e. a DNA sequence blocking transcription, followed by a diphtheria toxin receptor. The transgene is knocked-in inside the Calca locus. Hence, mice carrying two copies of the transgene lack functional Calca gene. As the STOP cassette contains a farnesylated Green Fluorescent Protein (GFP), cells with active Calca promoter can be visualised by GFP staining. Due to farnesylation, GFP is located in cell membranes, making passible to visualise projections of neurons with active Calca promoter. As Calca encodes not only $\operatorname{CGRP} \alpha$, but also procalcitonin, KO mice lack both peptides. 


\subsection{Inflammatory pain model: Formalin injections}

Local inflammatory pain can be induced in mice by injecting diluted formalin $(2.5 \%)$ under the skin of the hind paw. This causes a biphasic pain response: the first phase (0-5 min after the injection) is caused by a direct activation of sensory neurons (McNamara et al. 2007), hence it is insensitive to anti-inflammatory drugs, while the second phase (15-90 min) is inflammatory (McNamara et al. 2007; Hunskaar et al. 1987). To reduce stress levels, mice are under isoflurane anesthesia during the injection.

\section{Assessing the affective component of pain: Conditioned Place Aversion}

Mice's emotional responses can be assessed by observation of their behaviour. A commonly used test for accessing the affective component of pain in rodents is conditioned place aversion (CPA) (Alhadeff, Su, et al. 2018; Johansen et al. 2001). This paradigm is based on a natural tendency of mice to avoid the environment where they have experienced something potentially harmful.

In a laboratory setting, the environment where a mouse is exposed to pain is an apparatus with two chambers connected by a corridor. The chambers have distinctive patterns on their walls. Mice are allowed to explore this new environment for $15 \mathrm{~min}$ and the time spend in each chamber is measured (pretest). Next, the preferred chamber (i.e. the chamber where the mouse spent more time during the first exploration) is paired with pain, and the nonpreferred chamber is paired with the control intervention (so-called biased design). After this phase (conditioning phase), mice are allowed to freely explore the apparatus again, without being exposed to any interventions (posttest). The time spent in each chamber is measured once more. The results are expressed as the difference in time spent in the preferred chamber between the post- and pre-test, i.e. negative scores mean aversion.

If the aversion is not formed by an experimental group, two possibilities should be considered: either the experimental manipulation prevents perceiving the normally aversive stimulus as unpleasant, or the animals lack the ability to learn associations whatsoever. The second possibility can be excluded by performing a control test, where a different unconditioned stimulus

is used. In paper I, CPA induced by thermal pain was used as this type of control.

An alternative approach to assess the affective component of pain in mice has been proposed, based on observation of mice's face expressions (Langford et al. 2010). This approach has proved to be difficult to implement on black mice. 


\section{Assessing the sensory component of pain: Nociceptive scoring}

The sensory component of pain is commonly assessed in rodents by measuring the time spent on performing nociceptive behaviors (Alhadeff, $\mathrm{Su}$, et al. 2018; Hunskaar et al. 1987; McNamara et al. 2007). After the formalin injection mice are placed in a transparent plexiglass box and videotaped for 1h. A mirror is placed behind the box, so the animals can be observed from different angles. The time of lifting, shaking and licking the injected paw is measured. Some variations of this test focus only on paw licking. After comparing both versions and receiving similar course of response, we used the simplified approach.

\subsection{Systemic inflammation model: Intraperitoneal lipopolysaccharide injections}

The symptoms of systemic inflammation in humans, known as the sickness syndrome, include corticosteroid secretion, fever, decreased food intake, inactivity, feelings of discomfort/malaise and social withdrawal (Saper et al. 2012). Similar changes in physiology and behavior can be observed in mice upon intraperitoneal (i.p.) LPS administration. LPS is a component of outer membrane of Gram-negative bacteria. As one of the conserved pathogenassociated molecular patterns (PAMPs) LPS triggers innate immune response. In doses used in experiments on adult mice, $10 \mu \mathrm{g} / \mathrm{kg}$, it induces reduction in food intake and locomotor activity, without inducing sepsis-like symptoms or severe hyperthermia.

One of the biggest limitations of using LPS is its ability to induce tolerance. Because of that, it is only suitable for induction of acute, but not chronic inflammation.

\section{LPS-induced anorexia}

Reduction in food intake is a common symptom of systemic inflammation, easily modeled in mice. As all food intake measurements, LPS-induced anorexia experiments should be performed during the active (i.e. dark) phase. One hour before the onset of the dark phase animals are injected with LPS or saline. The chow is withdrawn, as some mice could start eating before the effects of LPS occur. At the onset of the dark phase, mice get access to food. The intake is measured 3 and 6 hours later. Because the test is performed in home cages, mice need to be single-housed. 


\section{Conditioned Taste Avoidance}

This test is based on creating an association between a novel taste and the inflammation-induced malaise. As a result, animals develop aversion to the specific taste. Because mice avoid novel foods (so-called taste neophobia), the conditioning needs to be preceded with water deprivation: thirsty mice are more likely to consume saccharin solution, even if they have not been exposed to sweetness before. After one hour of access to saccharin, mice are injected with LPS. Three days later (time needed to remove LPS from the system), mice get access to the sweet solution for the second time. The intake of saccharine solution is measured and compared with the control group, in which malaise was not induced. Mice drinking less than $0.5 \mathrm{~g}$ of saccharine solution during the conditioning day were excluded from statistical analysis, because consuming less than this amount was not enough to elicit reliable taste avoidance. This problem could be minimized in future by prolonging the time of water deprivation.

\section{Inflammatory challenge in presence or absence of the dam}

To study how stress influences inflammation in developing immune system, we combined two commonly used procedures: maternal separation and inflammatory challenge. The experiment was performed on pups at postnatal day 8-9 (PN8-9), when the period of the fastest brain growth starts (AvishaiEliner et al. 2002). Mice of this age are completely dependent on their dams, cannot eat solid food and their eyes are not opened. This stage of rodent development can be compared to 2-8-month-old human infant (Avishai-Eliner et al. 2002). Since the presence of the dam is crucial for survival, depriving pups of the presence of mother for prolonged time is a major stressor.

Mice were subjected to separation immediately after an inflammatory challenge, induced by i.p. injections of LPS $(40 \mathrm{\mu g} / \mathrm{kg})$. The litters were split and moved to new cages either with or without a dam. Moving mice to a novel environment is a stressor on its own, but in this way the stressfulness of the environment did not differ between the groups. During the experiment dams and their litters were kept in the same room, making it possible to maintain some level of communication through odors and vocalizations. The separation eliminated other aspects of maternal care, such as feeding, active touch (licking) and passive touch (providing warmth and softness). To substitute for passive touch, one experimental group was exposed to Warm and Soft Object (WSOb): a hand warmer wrapped in fleece. The temperature of fleece ranged from $32.5^{\circ} \mathrm{C}$ to $35.5^{\circ} \mathrm{C}$ and pups could crawl to area of the temperature of their choice. The other groups were kept in $26-27^{\circ} \mathrm{C}$, temperatures slightly below the range at which adult mice do not have to spend energy on thermoregulation. 
Tissue samples were collected at 1 or 3 hours after injection. Hypothalamus was chosen for its role in regulation of inflammatory response and CORT release. Since proinflammatory gene expression can differ between brain and periphery, we measured mRNA expression in the liver as well.

\subsection{Ex vivo studies}

\section{Immunofluorescence}

Immunofluorescence is an antibody-based method commonly used for visualisation of macromolecules in preserved tissue. It especially popular when visualisation of two or more antigens is required, in order to verify their colocalization.

In paper I immunofluorescence was used for assessing specificity of the SertCre line and validation of viral injections. To visualise serotonergic neurons, we used an antibody detecting tryptophan hydroxylase (Tph), an enzyme involved in serotonin synthesis. Tph staining was combined with antibody-based detection of either Cre or marker proteins encoded by transgenes carried by AAVs. Although the marker proteins can emit fluorescence on its own, immunofluorescence was used to amplify the signal and increase detection sensitivity.

In paper II, immunofluorescent staining was performed to confirm that CGRP is absent in the PBN of CGRP-KO mice. The residual staining visible in this area could be explained by low-level unspecific binding of the primary antibody. However, this possibility seems unlikely, because the residual staining is restricted to the area where Calca is normally expressed. The more plausible explanation is that the source of the signal is the second isoform of CGRP, encoded by a separate gene, Calcb (Amara et al. 1985). Although very often wrongly stated in the literature, $\operatorname{CGRP} \beta$ is not only present in the enteric nervous system, but also in the CNS, e.g. in different cranial nerve nuclei, where it is co-expressed with Calca (Amara et al. 1985). As the isoforms differ only in three amino acids (Thomas et al. 2001), they are undistinguishable by antibody-based methods. This issue was not addressed by more specific methods, as it would be baffling if $\operatorname{CGRP} \beta$ present in levels barely detectable by immunofluorescence could substitute for normal levels of $\operatorname{CGRP} \alpha$.

\section{Quantitative Polymerase Chain Reaction (qPCR)}

Quantitative Polymerase Chain Reaction (qPCR) is a commonly used technique for measuring the amount of specific RNAs.

In paper I, qPCR was used for assessing the effectiveness of deletion of the EP3R from the DRN. This method of validation is a popular choice when no antibodies detecting the product of the deleted gene are available. The 
downside of this approach is its lack of spatial resolution - the mRNA is extracted from all the cells in the region of interest, not only from a specific cell-type (in this case - serotonergic neurons). For that reason, the levels of EP3R mRNA cannot be expected to be reduced to zero. The alternative approach - currently obvious - would be using fluorescent in situ hybridization methods, which had improved greatly the last couple of years.

In paper III, qPCR was used to assess the strength of the proinflammatory response through measuring proinflammatory gene expression.

In both papers the purpose of the qPCR experiments was to compare the change in gene expression between the experimental and the control groups, hence the relative, not absolute, quantification method was chosen.

In paper III, in order to simplify the text, I write about „expression levels of $<$ protein name $>$ ", instead of "expression levels of $<$ gene name $>$ " (for example "expression levels of Cox-2" instead of "expression levels of Ptgs2"), as protein names are better known.

\subsection{Sex of animals used}

All experiments described in paper I were performed on male mice. In paper II, we used both males and females (formalin test - females, CTA - mixed sexes, inflammation-induced anorexia - males, CPA - males). Pups in paper III were both male and female. In experiments where both sexes were used we did not observed differences between male and female mice.

\subsection{Statistical analysis}

The experiments in paper I and II are based on a comparison of two groups (control and experimental). In such cases student t-test was performed. In paper III we used a two-factorial design, hence two-way ANOVA was used. Subsequently, Pearson's correlation and factor analysis (principal component analysis, PCA) were performed, in order to group different variables analysed. The p-values above 0.05 were considered statistically significant. Bars represent mean values \pm standard error of the mean. 



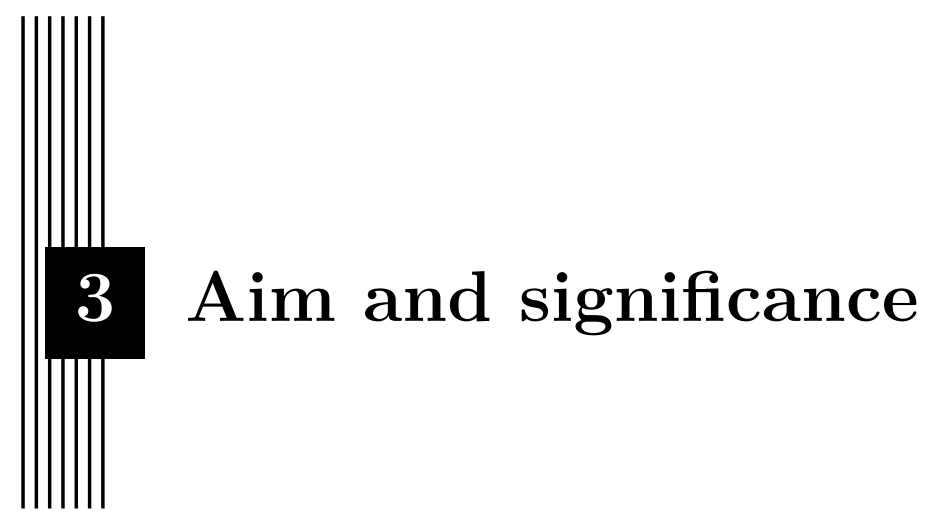

The aim of the thesis was to better understand the communication between the immune and the nervous system during inflammation. More specifically, we tried to answer the following questions:

Paper I: How does inflammatory pain elicit a negative affective state?

Paper II: Is CGRP $\alpha$ necessary for pain-related behaviours and inflammation-induced anorexia?

Paper III: How does emotional stress influence the immune response in early life?

Although the inflammation theory of depression is not the topic this thesis, the phenomena studied here might shed light on how inflammatory processes elicit behavioural changes resembling symptoms of depression. Understanding which circuits trigger these behavioural changes can help to pinpoint the 'weak spots' dysregulation of which leads to depression. 



\section{Results and discussion}

\subsection{Paper I: Prostaglandin-mediated inhibition of serotonin signaling controls the affective component of inflammatory pain}

In this paper, we focused on affective aspect of the inflammatory pain. CPA induced by formalin injection was used to assess the affective dimension of pain in mice, while the sensory component was measured by scoring nociceptive behaviours (the formalin test). First, we studied how genetic deletions of different parts of the prostaglandin synthesis pathway influence the perception of pain. In the next step, we employed injections of viral vectors to assess which brain areas are responsible for eliciting the unpleasant feeling associated with pain. Subsequently, we tested if activation or inhibition of specific neuronal populations influences pain aversion.

\section{Activation of EP3 receptors by PGE2 of neural origin influences the affective component of inflammatory pain}

Although prostanoids are well-known for their involvement in pain signalling on different levels of the nervous system (L. Chen et al. 2013), not much is known about their role in generation of the negative feelings elicited by pain. We tested if prostanoids produced by Cox-1 or Cox- 2 are necessary for eliciting the affective component of inflammatory pain. Mice with deletion of the gene encoding Cox-1 showed intact CPA, while mice lacking Cox-2 did 
not form aversion to the environment paired with inflammatory pain. These results were confirmed by pharmacological interventions.

Next, we assessed the cellular origin of prostanoids produced by Cox2. Cell-type specific Cre lines were used to delete the gene encoding Cox-2 from myeloid cells, brain endothelial cells and neural cells (i.e. neurons and macroglia). Only deletion in neural cells resulted in loss of aversion. The exact nature of those cells remains unknow.

Knowing that mPGES-1 is important for nociceptive and systemic inflammatory responses (L. Chen et al. 2013), we tested the effects of its deletion. mPGES-1-KO mice were unable to form aversion towards the environment paired with formalin injection. The product of mPGES-1, PGE2, acts through 4 types of receptors, EP1-4 (Sugimoto et al. 2007). We tested the effects of deletion of EP1R and EP3R, as they are expressed in brain areas involved in motivation and nociception. EP3R deletion, but not EP1R deletion, abolished the ability to acquire aversion.

\section{The EP3 receptors mediating the affective component of inflammatory pain are located on serotonergic cells}

Among many areas of the CNS where EP3Rs are expressed, we decided to target the serotonergic cells of the DRN, due to the involvement of serotonin (5-hydroxytryptamine, 5-HT) in affective control (Dayan et al. 2009) and aversion (Amo et al. 2014). In the first step, we deleted EP3Rs from all serotonergic neurons. This intervention had the same effect as global EP3R deletion, i.e. EP3R $\mathrm{R}^{\text {SertCre }}$ mice did not develop aversion in the CPA paradigm. We performed additional controls to check if this effect is specific to inflammatory pain or if removing EP3Rs from serotonergic cells disturbs aversion learning in general. EP3R ${ }^{\text {SertCre }}$ mice developed normal aversion to thermal pain and to kappa opioid receptor agonist.

Importantly, removing EP3Rs exclusively from the serotonergic neurons did not affect the sensory component of pain. Mice without EP3Rs showed intact nociceptive responses, opposite to global mPGES-1-KOs. This indicates that although PGE2 is involved in both sensory and affective components of pain, its effects on serotonergic transmission are limited to the affective dimension.

To strengthen this finding, we performed CPA on mice with SERT deletion, which disturbs normal serotonergic signalling. SERT-KO mice did not develop aversion to the environment paired with formalin injection.

\section{Inhibition of the serotonergic neurons of the dorsal raphe mediates the affective component of pain}

In the next step, we targeted EP3Rs on the DRN, a nucleus containing serotonergic neurons projecting to forebrain structures (Waselus et al. 2011). The 


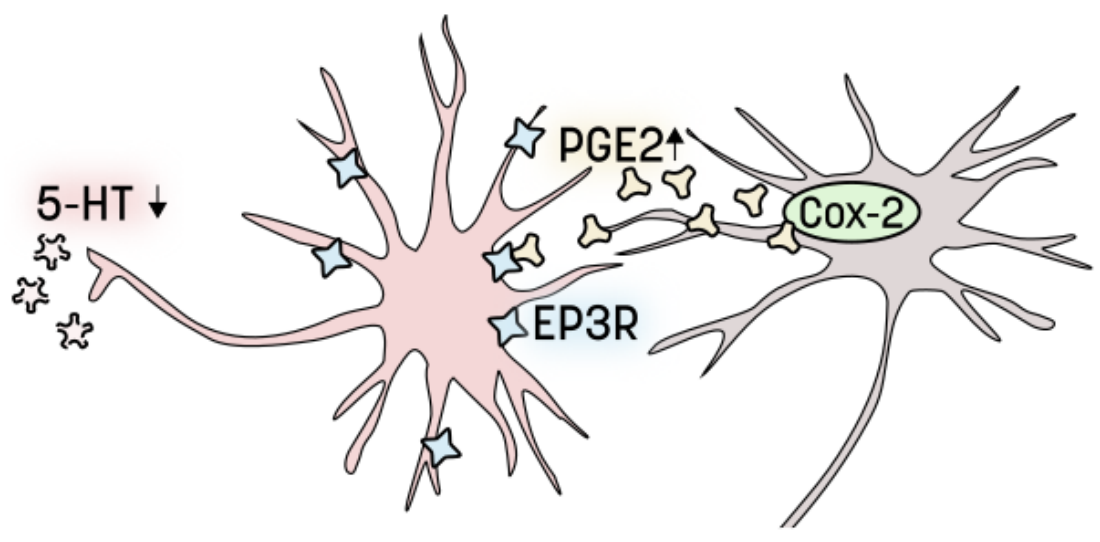

Figure 4.1: Suggested mechanism of the affective component of inflammatory pain: 1. PGE2 is produced in neural cells through Cox-2. 2. PGE2 binds to EP3 receptors on serotonergic cells of the DRN. 3. EP3 receptor activation leads to inhibition of serotonergic cells.

deletion was achieved through local injections of viral vectors (AAV-Cre). The mice injected AAV-Cre did not display aversion to the chamber paired with pain, opposite to mice injected with the control vectors. This implies that the affective component of pain is mediated by the EP3Rs selectively on the DRN.

It is worth to note that even if the DRN neurons project mostly to the forebrain structures (Waselus et al. 2011), there is an evidence for very scarce descending projections from the DRN to the spinal level (Bowker et al. 1981). Nevertheless, as removing EP3Rs from all serotonergic cells does not influence the nociceptive responses to formalin injection, we conclude that the possibility of targeting the scarce descending projections does not change the interpretation of this experiment.

Knowing that most EP3R isoforms are coupled to inhibitory G proteins (Sugimoto et al. 2007), we investigated if EP3R signalling mediates aversion through inhibition of serotonergic neurons. Chemogenetic stimulation of 5HT neurons of the DRN during pain blocked the aversion. Furthermore, even if EP3R $\mathrm{R}^{\text {SertCre }}$ mice were unable to form aversion to inflammatory pain, substituting the EP3R with inhibitory DREADDs in the DRN reconstitutes aversion learning. Those findings support the notion that EP3R activation elicits aversion by inhibition of serotonergic neurons. 
The suggested mechanism of prostaglandin-dependent pain aversion is summarised in figure 4.1 .

Knowing that serotonergic neurons of the DRN are activated by other aversive (Cohen et al. 2015) and noxious stimuli (Schweimer et al. 2010), we can speculate that other types of pain could also reach serotonergic cells through other routes, not involving EP3Rs.

As serotonergic neurons of the DRN project throughout the whole forebrain (Waselus et al. 2011), there are several areas where serotonin could modulate pain processing in order to elicit negative mood and aversion. The best candidates seem to be the ACC, for its well-established role in the affective component of pain (Johansen et al. 2001, Price 2000, Rainville et al. 1997), the amygdala, being a structure linking nociception and emotion (Neugebauer 2015) or the nucleus accumbens, as some forms of aversion were demonstrated to encoded by a DRN to nucleus accumbens projection (Land et al. 2009).

\subsection{Paper II: Calcitonin gene related peptide $\alpha$ is dispensable for many danger-related motivational responses}

In this project, we studied the role of $\operatorname{CGRP} \alpha$ in mediating the effects of activation of CGRP ${ }^{\mathrm{PBN}}$ neurons by pain and inflammation. We used $\operatorname{CGRP} \alpha$ Knock-Out mice and performed a series of behavioural tests.

\section{$\operatorname{CGRP} \alpha$ is absent in the projections to the central amygdala in $\operatorname{CGRP} \alpha-\mathrm{KO}$ mice}

In order to confirm the loss of CGRP in the parabrachio-amygdaloid pathway, we performed immunohistochemical staining in the $\mathrm{PBN}$ and in the CeA. In the PBN, the loss of CGRP was almost complete. The residual staining can be attributed to low levels of the second isoform of CGRP, CGRP $\beta$. Nevertheless, barely detectable levels CGRP $\beta$ could not substitute for normal levels of CGRP $\alpha$. Moreover, no CGRP immunoreactive fibers were observed in the central amygdala.

\section{CGRP signaling is not necessary for inflammation induced anorexia and conditioned taste aversion}

CGRP $^{\text {PBN }}$ neurons activation was shown to block food intake in various conditions (Alhadeff, Su, et al. 2018, Campos et al. 2018), while inhibition diminished LPS-induced anorexia (Carter, Soden, et al. 2013). To test if CGRP is necessary for the hypophagia during inflammation, we injected CGRP $\alpha$-KO mice with LPS and subsequently measured their chow intake. Mutant mice decreased their food intake to the same levels as controls. 
Knowing that $\mathrm{CGRP}^{\mathrm{PBN}}$ neurons are involved in acquisition and expression of CTA (Carter, S. Han, et al. 2015, J. Y. Chen et al. 2018), we tested if CGRP $\alpha$ is necessary for developing aversion to malaise-inducing food. Deletion of CGRP $\alpha$ did not attenuate aversion to the taste paired with LPS administration.

\section{CGRP signaling is not necessary for pain-related behaviors}

As parabrachial-amygdaloid pathway was shown to be involved in nocifensive behaviours (Campos et al. 2018, S. Han et al. 2015) and CGRP is involved in pain signaling also on the peripheral and spinal level (Russell et al. 2014), we assessed nociceptive responses to inflammatory pain induced by diluted formalin injection in $\mathrm{CGRP} \alpha$-KO mice. Surprisingly, mice lacking $\operatorname{CGRP} \alpha$ showed completely normal nociceptive responses, assessed by measuring the time spent on licking the injected paw. This result is contradictory to what was previously reported in literature (Salmon, Damaj, Marubio, et al. 2001, Shinohara et al. 2017). The discrepancies could be explained by sex differences, as our study was done on females, while the aforementioned papers either do no state which sex was used, or used both males and females.

Parabrachial-amygdaloid pathway was also shown to mediate affective responses to pain (S. Han et al. 2015). To assess the role of CGRP $\alpha$ in creating negative feelings elicited by pain, we tested the ability of CGRP $\alpha$-KO mice to form aversion to thermal pain in CPA paradigm. Thermal pain was used, as multiple studies show that $\mathrm{CGRP} \alpha$-KO mice have intact acute nociceptive responses to heat (S. Han et al. 2015, Salmon, Damaj, Sekine, et al. 1999, Zhang et al. 2001). Our study shows that the affective responses to thermal pain are also not affected in the mutant mice.

Together, these results demonstrate that the parabrachial neurons expressing CGRP use different signaling molecules (most probably glutamate (Alhadeff, Holland, et al. 2017)) to mediate most inflammation- and pain-related behaviours. It is not unusual that a peptide defining a specific population of neurons is not necessary for mediating the effects of their activation. Deletion of AgRP has no (Qian et al. 2002) or very limited (Wortley et al. 2005) effect on feeding and energy homeostasis, opposite to activation, inactivation or ablation of the neurons expressing this neuropeptide (Gropp et al. 2005, Luquet et al. 2005, Aponte et al. 2011, Krashes et al. 2011).

Nevertheless, as the lack of any behavioral phenotype could raise questions about the functional effects of the mutation, it is important to mention that the same mouse line was used in Wilhelms et al. 2018, where we showed that the mutation attenuates hot flushes in a mouse model of menopause.

Seeing no effect of CGRP $\alpha$ deletion in our study, we cannot exclude that the peptide is not involved in reduction of food intake and pain signaling in other settings. For example, CGRP $\alpha$ enhances synaptic plasticity in the 
amygdala during chronic inflammatory pain and was proposed to exaggerate the emotional response to pain during this condition (J. S. Han et al. 2005, Shinohara et al. 2017). It is also possible that CGRP $\alpha$ potentiates the effects of other neurotransmitters and our study was not powerful enough to detect those small effects.

\subsection{Paper III: Acute maternal separation potentiates the gene expression and corticosterone response induced by inflammation}

In this project, we investigated how emotional stress - separation from the dam - affects the immune response in 8-9-day-old pups. We also assessed if the effects of stress can be attenuated by providing pups with a warm, soft object, substituting some aspects of maternal presence. Systemic inflammation was induced by injections of bacterial endotoxin and the inflammatory gene expression and the corticosterone levels were measured.

\section{Maternal separation slightly attenuates proinflammatory gene induction one hour after inflammatory challenge without affecting CORT levels}

One hour after the immune challenge we observed elevation in proinflammatory transcripts in the liver. IL-1 $\beta$, C-X-C Motif Chemokine 10 (Cxcl10) and Cox-2 transcript levels were increased to higher extent in the group staying with the dam and there was a tendency in the same direction for interleukin-6 (IL-6), Tumor Necrosis Factor $\alpha$ (TNF $\alpha)$ and C-C Motif Chemokine Ligand 2 ( $\mathrm{Ccl} 2)$. As cytokine production in brain is delayed comparing to the periphery (Dantzer 2018), the induction of proinflammatory transcripts was less pronounced in the hypothalamus. The upregulation occurred only in pups staying with the dam and only for IL- $1 \beta$ and Cox- 2 .

As pro-inflammatory cytokines induce CORT secretion (Besedovsky et al. 1986), even during the stress hyporesponsive period (Dent et al. 1999; WitekJanusek 1988), we measured CORT levels in the blood. Maternal separation lasting $1 \mathrm{~h}$ did not influence the CORT response to LPS, as CORT levels were elevated after LPS administration to the same extent in both separated and non-separated pups. These observations are consistent with previous findings. CORT response to stressors during SHRP strongly depends on maternal presence (Kent et al. 1997; Stanton, Gutierrez, et al. 1988), however, one hour separation might be too short to see this effect, as maternal separation of the same duration was previously reported not to increase novelty stress-induced CORT release (Stanton, Gutierrez, et al. 1988). 
4.3. Paper III: Acute maternal separation potentiates the gene expression and corticosterone response induced by inflammation

\section{Maternal separation potentiates proinflammatory gene induction and CORT response three hours after inflammatory challenge}

Three hours after the immune challenge the effects of maternal separation were more pronounced. Stressed pups had higher levels of transcripts of genes encoding IL-1 $\beta$, IL-6, Cxcl10, Ccl2 and Cox-2 in the liver and IL-1 $\beta$, IL-6, TNF $\alpha$, Cxcl10, Ccl2 and Cox- 2 in the hypothalamus. CORT response to LPS was also increased in animals staying without the dam.

It seems unlikely that the differences in proinflammatory gene expression result from HPA-axis activation, as the immune-stimulating effects of glucocorticoids are reported when the stressful event/CORT administration precede inflammation (Sorrells et al. 2009). Conversely, it is more probable that the augmented inflammatory response caused the increase in CORT levels in blood, as separation stress potentiated the expression of proinflammatory transcripts at the same time point as the higher CORT response occurred. Additionally, separation stress can increase the sensitivity of HPA-axis during the SHRP (Kent et al. 1997; Stanton, Gutierrez, et al. 1988).

\section{A warm and soft object attenuates some of the effects of separation stress}

To determine if the absence of factors related to passive contact with the mother mediates the separation effects, we provided pups with access to a warm, soft object (WSOb). WSOb normalized gene expression of IL-6, Cxcl10 and $\mathrm{Ccl} 2$ in the hypothalamus and in the liver but had little or no effect on IL$1 \beta, \mathrm{TNF} \alpha$ and Cox-2. Importantly, the effect of maternal separation on the CORT response to inflammation was almost completely blocked by WSOb.

These findings go in line with studies showing that passive touch is very important for pups. Contact with an anaesthetised female (hence non-lactating and not providing care) is sufficient to inhibit CORT secretion upon novel environment stress (Stanton, Wallstrom, et al. 1987) and young rat pups prefer to huddle with a soft object slightly warmer than a dam over huddling with an actual dam, although this behaviour changes with age (Alberts et al. 1978). Hence, the normalization of the CORT response mediated by the WSOb could be explained both by lower levels of proinflammatory cytokines and by lower sensitivity of the HPA-axis to factors eliciting CORT release in general.

Further studies would be needed to assess if the effects of WSOb were mediated by combination of softness and warmth, by one of these factors alone or if some aspects are mediated by softness and others by warmth. Nevertheless, these results indicate that different manifestations of maternal care regulate different inflammatory genes or that different inflammatory genes have different sensitivity to maternal deprivation. 


\section{Corticosterone levels correlate with IL-6, Ccl2 and hepatic IL-1 $\beta$ expression}

To integrate the results of gene expression analysis and CORT assay, we performed principal component analysis (PCA). The analysis revealed two groups of variables regulated in a similar manner. The first group includes CORT, Ccl2 and IL-6 (both in the liver and the hypothalamus) as well as hepatic IL- $1 \beta$, which indicates that these cytokines are similarly regulated as (or even trigger) CORT secretion. In general, this group contains genes normalized by WSOb, but also hepatic IL- $\beta$, insensitive to WSOb presence.

The second group includes Cox- 2 and $\mathrm{TNF} \alpha$ (both in the hypothalamus and the liver) as well as hypothalamic IL- $1 \beta$, and weakly correlates with CORT. Although Cox-2 is an enzyme involved in production of PGE2, which in turn is required for HPA-axis activation and CORT secretion, this result is not surprising, as at this time point PGE2 activating HPA-axis might be still of Cox-1 origin.

Further studies would be needed to elucidate the mechanism(s) mediating the buffering effects of maternal care on the immune response. 


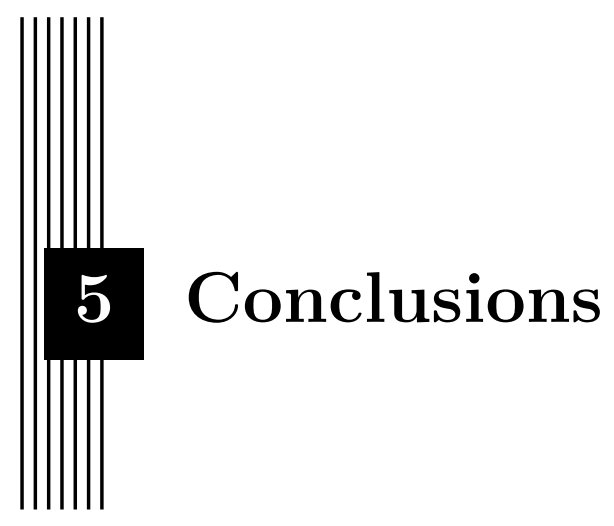

\subsection{Paper I: Prostaglandin-mediated inhibition of serotonin signaling controls the affective component of inflammatory pain}

In paper I, we reveal a mechanism of induction of negative affect by inflammatory pain: prostaglandin E2, produced through Cox-2 in neural cells, binds to EP3 receptors on serotonergic cells in the dorsal raphe nucleus. The resulting inhibition of serotonergic neurons gives rise to negative feelings and subsequent aversion.

\subsection{Paper II: Calcitonin gene related peptide $\alpha$ is dispensable for many danger-related motivational responses}

We show that CGRP $\alpha$ is dispensable for many pain- and inflammation-related behaviours mediated by CGRP $\alpha$-expressing neurons in the parabrachial nucleus. CGRP $\alpha$ might be involved in other processes, especially requiring changes in synaptic plasticity. 


\subsection{Paper III: Acute maternal separation potentiates the gene expression and corticosterone response induced by inflammation}

We demonstrate that acute maternal separation potentiates pro-inflammatory gene expression and CORT secretion in response to systemic inflammation. The effects was observed in 8-9 days old pups, i.e. at the developmental stage comparable to to 2-8-month-old human infant (Avishai-Eliner et al. 2002). Our results suggest that different aspects of maternal care regulate expression of different groups of genes, as substituting for passive touch (providing pups with a warm and soft object) normalized the response to immune challenge for some, but not all, pro-inflammatory genes studied. 


\section{Bibliography}

Alberts, J. R. and Brunjes, P. C. (1978). "Ontogeny of thermal and olfactory determinants of huddling in the rat". In: J Comp Physiol Psychol 92.5, pp. 897-906. ISSN: 0021-9940 (Print) 0021-9940. URL: https://www.ncbi. nlm.nih.gov/pubmed/730859.

Alexander, G. M., Rogan, S. C., Abbas, A. I., Armbruster, B. N., Pei, Y., Allen, J. A., Nonneman, R. J., Hartmann, J., Moy, S. S., Nicolelis, M. A., McNamara, J. O., and Roth, B. L. (2009). "Remote control of neuronal activity in transgenic mice expressing evolved G protein-coupled receptors". In: Neuron 63.1, pp. 27-39. ISSN: 1097-4199 (Electronic) 0896-6273. DOI: 10.1016/j.neuron . 2009.06 .014. URL: https : //www . ncbi .nlm.nih . gov/pubmed/19607790.

Alhadeff, A. L., Holland, R. A., Zheng, H., Rinaman, L., Grill, H. J., and De Jonghe, B. C. (2017). "Excitatory Hindbrain-Forebrain Communication Is Required for Cisplatin-Induced Anorexia and Weight Loss". In: J Neurosci 37.2, pp. 362-370. ISSN: 1529-2401 (Electronic) 0270-6474 (Linking). DOI: 10.1523/JNEUROSCI.2714-16.2016. URL: https://www.ncbi.nlm.nih. gov/pubmed/28077715.

Alhadeff, A. L., Su, Z., Hernandez, E., Klima, M. L., Phillips, S. Z., Holland, R. A., Guo, C., Hantman, A. W., De Jonghe, B. C., and Betley, J. N. (2018). "A Neural Circuit for the Suppression of Pain by a Competing Need State". In: Cell 173.1, 140-152 e15. ISSN: 1097-4172 (Electronic) 0092-8674. DOI: $10.1016 /$ j.cell.2018.02.057. URL: https://www.ncbi.nlm.nih. gov/pubmed/29570993. 
Amara, S. G., Arriza, J. L., Leff, S. E., Swanson, L. W., Evans, R. M., and Rosenfeld, M. G. (1985). "Expression in brain of a messenger RNA encoding a novel neuropeptide homologous to calcitonin gene-related peptide". In: Science 229.4718, pp. 1094-7. ISSN: 0036-8075 (Print) 0036-8075. URL: https://www.ncbi.nlm.nih.gov/pubmed/2994212.

Amo, R., Fredes, F., Kinoshita, M., Aoki, R., Aizawa, H., Agetsuma, M., Aoki, T., Shiraki, T., Kakinuma, H., Matsuda, M., Yamazaki, M., Takahoko, M., Tsuboi, T., Higashijima, S., Miyasaka, N., Koide, T., Yabuki, Y., Yoshihara, Y., Fukai, T., and Okamoto, H. (2014). "The habenulo-raphe serotonergic circuit encodes an aversive expectation value essential for adaptive active avoidance of danger". In: Neuron 84.5, pp. 1034-48. ISSN: 1097-4199 (Electronic) 0896-6273 (Linking). DOI: 10.1016/j .neuron. 2014.10.035. URL: https://www.ncbi.nlm.nih.gov/pubmed/25467985.

Aponte, Y., Atasoy, D., and Sternson, S. M. (2011). "AGRP neurons are sufficient to orchestrate feeding behavior rapidly and without training". In: Nat Neurosci 14.3, pp. 351-5. ISSN: 1546-1726 (Electronic) 1097-6256 (Linking). DOI: 10.1038/nn . 2739. URL: https ://www . ncbi.nlm.nih . gov/pubmed/21209617.

Armbruster, B. N., Li, X., Pausch, M. H., Herlitze, S., and Roth, B. L. (2007). "Evolving the lock to fit the key to create a family of G protein-coupled receptors potently activated by an inert ligand". In: Proc Natl Acad Sci U $S A$ 104.12, pp. 5163-8. ISSN: 0027-8424 (Print) 0027-8424. DOI: $10.1073 /$ pnas . 0700293104. URL: https : / / www .ncbi .nlm . nih.gov/pubmed/ 17360345.

Aschauer, D. F., Kreuz, S., and Rumpel, S. (2013). "Analysis of transduction efficiency, tropism and axonal transport of AAV serotypes 1, 2, 5, 6, 8 and 9 in the mouse brain". In: PLoS One 8.9, e76310. ISSN: 1932-6203 (Electronic) 1932-6203. DOI: $10.1371 /$ journal pone.0076310. URL: https : //www . ncbi.nlm.nih.gov/pubmed/24086725.

Avishai-Eliner, S., Brunson, K. L., Sandman, C. A., and Baram, T. Z. (2002). "Stressed-out, or in (utero)?" In: Trends Neurosci 25.10, pp. 518-24. ISSN: 0166-2236 (Print) 0166-2236. URL: https : / / www . ncbi .nlm . nih . gov/ pubmed/12220880.

Avitsur, R. and Sheridan, J. F. (2009). "Neonatal stress modulates sickness behavior". In: Brain Behav Immun 23.7, pp. 977-85. ISSN: 1090-2139 (Electronic) 0889-1591. DOI: $10.1016 / \mathrm{j} . \mathrm{bbi} .2009 .05 .056$. URL: https : //www.ncbi.nlm.nih.gov/pubmed/19464359.

Bair, M. J., Robinson, R. L., Katon, W., and Kroenke, K. (2003). "Depression and pain comorbidity: a literature review". In: Arch Intern Med 163.20, pp. 2433-45. ISSN: 0003-9926 (Print) 0003-9926. DOI: 10.1001/archinte. 163.20.2433. URL: https://www.ncbi.nlm.nih.gov/pubmed/14609780.

Bellavance, M. A. and Rivest, S. (2014). "The HPA - Immune Axis and the Immunomodulatory Actions of Glucocorticoids in the Brain". In: Front Immunol 5, p. 136. ISSN: 1664-3224 (Print) 1664-3224. DOI: $10.3389 /$ 
fimmu . 2014.00136. URL: https : //www .ncbi.nlm.nih.gov/pubmed/ 24744759.

Ben-Shaanan, T. L., Azulay-Debby, H., Dubovik, T., Starosvetsky, E., Korin, B., Schiller, M., Green, N. L., Admon, Y., Hakim, F., Shen-Orr, S. S., and Rolls, A. (2016). "Activation of the reward system boosts innate and adaptive immunity". In: Nat Med 22.8, pp. 940-4. ISSN: 1546-170X (Electronic) 1078-8956. DOI: $10.1038 / \mathrm{nm}$.4133. URL: https : //www .ncbi.nlm.nih . gov/pubmed/27376577.

Ben-Shaanan, T. L., Schiller, M., Azulay-Debby, H., Korin, B., Boshnak, N., Koren, T., Krot, M., Shakya, J., Rahat, M. A., Hakim, F., and Rolls, A. (2018). "Modulation of anti-tumor immunity by the brain's reward system". In: Nat Commun 9.1, p. 2723. ISSN: 2041-1723 (Electronic) 20411723. DOI: $10.1038 /$ s41467-018-05283-5. URL: https : //www . ncbi . nlm.nih.gov/pubmed/30006573.

Besedovsky, H., Rey, A. del, Sorkin, E., and Dinarello, C. A. (1986). "Immunoregulatory feedback between interleukin-1 and glucocorticoid hormones". In: Science 233.4764, pp. 652-4. ISSN: 0036-8075 (Print) 0036-8075. URL: https://www.ncbi.nlm.nih.gov/pubmed/3014662.

Blomqvist, A. and Engblom, D. (2018). "Neural Mechanisms of InflammationInduced Fever". In: Neuroscientist 24.4, pp. 381-399. ISSN: 1089-4098 (Electronic) 1073-8584. DOI: 10.1177/1073858418760481. URL: https: //www.ncbi.nlm.nih.gov/pubmed/29557255.

Bowker, R. M., Westlund, K. N., and Coulter, J. D. (1981). "Origins of serotonergic projections to the spinal cord in rat: an immunocytochemicalretrograde transport study". In: Brain Res 226.1-2, pp. 187-99. ISSN: 00068993 (Print) 0006-8993 (Linking). URL: https : //www.ncbi.nlm.nih. gov/pubmed/7028211.

Branda, C. S. and Dymecki, S. M. (2004). "Talking about a revolution: The impact of site-specific recombinases on genetic analyses in mice". In: Dev Cell 6.1, pp. 7-28. ISSN: 1534-5807 (Print) 1534-5807. URL: https : //www. ncbi.nlm.nih.gov/pubmed/14723844.

Campos, C. A., Bowen, A. J., Roman, C. W., and Palmiter, R. D. (2018). "Encoding of danger by parabrachial CGRP neurons". In: Nature 555.7698, pp. 617-622. ISSN: 1476-4687 (Electronic) 0028-0836. DOI: 10 . 1038/ nature25511. URL: https://www.ncbi.nlm.nih.gov/pubmed/29562230.

Carter, M. E., Han, S., and Palmiter, R. D. (2015). "Parabrachial calcitonin gene-related peptide neurons mediate conditioned taste aversion". In: $J$ Neurosci 35.11, pp. 4582-6. ISSN: 1529-2401 (Electronic) 0270-6474. DOI: 10.1523/JNEUROSCI .3729-14.2015. URL: https://www.ncbi.nlm.nih. gov/pubmed/25788675.

Carter, M. E., Soden, M. E., Zweifel, L. S., and Palmiter, R. D. (2013). "Genetic identification of a neural circuit that suppresses appetite". In: Nature 503.7474, pp. 111-4. ISSN: 1476-4687 (Electronic) 0028-0836. DOI: 
10.1038/nature12596. URL: https://www.ncbi.nlm.nih.gov/pubmed/ 24121436.

Cechetto, D. F., Standaert, D. G., and Saper, C. B. (1985). "Spinal and trigeminal dorsal horn projections to the parabrachial nucleus in the rat". In: J Comp Neurol 240.2, pp. 153-60. ISSN: 0021-9967 (Print) 0021-9967. DOI: $10.1002 /$ cne.902400205. URL: https : //www.ncbi.nlm.nih.gov/ pubmed/3840498.

Chen, J. Y., Campos, C. A., Jarvie, B. C., and Palmiter, R. D. (2018). "Parabrachial CGRP Neurons Establish and Sustain Aversive Taste Memories". In: Neuron 100.4, 891-899 e5. ISSN: 1097-4199 (Electronic) 08966273. DOI: $10.1016 / \mathrm{j}$.neuron.2018.09.032. URL: https://www.ncbi. nlm.nih.gov/pubmed/30344042.

Chen, L., Yang, G., and Grosser, T. (2013). "Prostanoids and inflammatory pain". In: Prostaglandins Other Lipid Mediat 104-105, pp. 5866. ISSN: 1098-8823 (Print) 1098-8823 (Linking). DOI: $10.1016 / \mathrm{j}$. prostaglandins . 2012.08.006. URL: https : //www . ncbi .nlm . nih . gov/pubmed/22981510.

Cohen, J. Y., Amoroso, M. W., and Uchida, N. (2015). "Serotonergic neurons signal reward and punishment on multiple timescales". In: Elife 4. ISSN: 2050-084X (Electronic) 2050-084X (Linking). DOI: 10.7554/eLife. 06346. URL: https://www.ncbi.nlm.nih.gov/pubmed/25714923.

Corder, G., Ahanonu, B., Grewe, B. F., Wang, D., Schnitzer, M. J., and Scherrer, G. (2019). "An amygdalar neural ensemble that encodes the unpleasantness of pain". In: Science 363.6424, pp. 276-281. ISSN: 1095-9203 (Electronic) 0036-8075. DOI: $10.1126 /$ science . aap8586. URL: https : //www.ncbi.nlm.nih.gov/pubmed/30655440.

Craig, A. D. (2003). "Interoception: the sense of the physiological condition of the body". In: Curr Opin Neurobiol 13.4, pp. 500-5. ISSN: 0959-4388 (Print) 0959-4388. URL: https://www.ncbi.nlm.nih.gov/pubmed/12965300.

Danese, A., Moffitt, T. E., Harrington, H., Milne, B. J., Polanczyk, G., Pariante, C. M., Poulton, R., and Caspi, A. (2009). "Adverse childhood experiences and adult risk factors for age-related disease: depression, inflammation, and clustering of metabolic risk markers". In: Arch Pediatr Adolesc Med 163.12, pp. 1135-43. ISSN: 1538-3628 (Electronic) 1072-4710. DOI: 10. 1001/archpediatrics . 2009 . 214. URL: https : //www . ncbi .nlm . nih.gov/pubmed/19996051.

Dantzer, R. (2018). "Neuroimmune Interactions: From the Brain to the Immune System and Vice Versa". In: Physiol Rev 98.1, pp. 477-504. ISSN: 1522-1210 (Electronic) 0031-9333. DOI: 10.1152/physrev.00039. 2016. URL: https://www.ncbi.nlm.nih.gov/pubmed/29351513.

Dayan, P. and Huys, Q. J. (2009). "Serotonin in affective control". In: Annu Rev Neurosci 32, pp. 95-126. ISSN: 1545-4126 (Electronic) 0147-006X (Linking). DOI: 10.1146/annurev . neuro.051508.135607. URL: https: //www.ncbi.nlm.nih.gov/pubmed/19400722. 
Dent, G. W., Smith, M. A., and Levine, S. (1999). "The ontogeny of the neuroendocrine response to endotoxin". In: Brain Res Dev Brain Res 117.1, pp. 21-9. ISSN: 0165-3806 (Print) 0165-3806. URL: https : //www .ncbi . nlm.nih.gov/pubmed/10536228.

Dube, S. R., Fairweather, D., Pearson, W. S., Felitti, V. J., Anda, R. F., and Croft, J. B. (2009). "Cumulative childhood stress and autoimmune diseases in adults". In: Psychosom Med 71.2, pp. 243-50. ISSN: 1534-7796 (Electronic) 0033-3174. DOI: 10 . 1097/PSY . Ob013e3181907888. URL: https : //www.ncbi.nlm.nih.gov/pubmed/19188532.

Dwarkasing, J. T., Marks, D. L., Witkamp, R. F., and Norren, K. van (2016). "Hypothalamic inflammation and food intake regulation during chronic illness". In: Peptides 77, pp. 60-6. ISSN: 1873-5169 (Electronic) 0196-9781. DOI: $10.1016 / j$.peptides.2015.06.011. URL: https://www.ncbi.nlm. nih.gov/pubmed/26158772.

Elander, L., Engstrom, L., Ruud, J., Mackerlova, L., Jakobsson, P. J., Engblom, D., Nilsberth, C., and Blomqvist, A. (2009). "Inducible prostaglandin E2 synthesis interacts in a temporally supplementary sequence with constitutive prostaglandin-synthesizing enzymes in creating the hypothalamic-pituitary-adrenal axis response to immune challenge". In: J Neurosci 29.5, pp. 1404-13. ISSN: 1529-2401 (Electronic) 0270-6474. DOI: $10.1523 /$ JNEUROSCI .5247-08.2009. URL: https ://www.ncbi.nlm. nih.gov/pubmed/19193887.

Frank, M. G., Weber, M. D., Watkins, L. R., and Maier, S. F. (2015). "Stress sounds the alarmin: The role of the danger-associated molecular pattern HMGB1 in stress-induced neuroinflammatory priming". In: Brain Behav Immun 48, pp. 1-7. ISSN: 1090-2139 (Electronic) 0889-1591. DOI: 10.1016/ j.bbi.2015.03.010. URL: https://www.ncbi.nlm.nih.gov/pubmed/ 25816800 .

Gomez, J. L., Bonaventura, J., Lesniak, W., Mathews, W. B., Sysa-Shah, P., Rodriguez, L. A., Ellis, R. J., Richie, C. T., Harvey, B. K., Dannals, R. F., Pomper, M. G., Bonci, A., and Michaelides, M. (2017). "Chemogenetics revealed: DREADD occupancy and activation via converted clozapine". In: Science 357.6350, pp. 503-507. ISSN: 1095-9203 (Electronic) 0036-8075. DOI: $10.1126 /$ science . aan2475. URL: https : / / www . ncbi.nlm.nih . gov/pubmed/28774929.

Gropp, E., Shanabrough, M., Borok, E., Xu, A. W., Janoschek, R., Buch, T., Plum, L., Balthasar, N., Hampel, B., Waisman, A., Barsh, G. S., Horvath, T. L., and Bruning, J. C. (2005). "Agouti-related peptide-expressing neurons are mandatory for feeding". In: Nat Neurosci 8.10, pp. 1289-91. ISSN: 1097-6256 (Print) 1097-6256 (Linking). DOI: 10.1038/nn1548. URL: https://www.ncbi.nlm.nih.gov/pubmed/16158063.

Gunnar, M. R. and Donzella, B. (2002). "Social regulation of the cortisol levels in early human development". In: Psychoneuroendocrinology 27.1-2, 
pp. 199-220. ISSN: 0306-4530 (Print) 0306-4530. URL: https : //www.ncbi. nlm.nih.gov/pubmed/11750779.

Han, J. S., Li, W., and Neugebauer, V. (2005). "Critical role of calcitonin gene-related peptide 1 receptors in the amygdala in synaptic plasticity and pain behavior". In: J Neurosci 25.46, pp. 10717-28. ISSN: 1529-2401 (Electronic) 0270-6474. DOI: 10 . 1523/ JNEUROSCI . 4112-05 . 2005. URL: https://www.ncbi.nlm.nih.gov/pubmed/16291945.

Han, S., Soleiman, M. T., Soden, M. E., Zweifel, L. S., and Palmiter, R. D. (2015). "Elucidating an Affective Pain Circuit that Creates a Threat Memory". In: Cell 162.2, pp. 363-374. ISSN: 1097-4172 (Electronic) 0092-8674. DOI: $10.1016 /$ j.cell.2015.05.057. URL: https://www.ncbi.nlm.nih. gov/pubmed/26186190.

Haroon, E., Raison, C. L., and Miller, A. H. (2012). "Psychoneuroimmunology meets neuropsychopharmacology: translational implications of the impact of inflammation on behavior". In: Neuropsychopharmacology 37.1, pp. 13762. ISSN: 1740-634X (Electronic) 0893-133X. DOI: 10.1038/npp. 2011.205. URL: https://www.ncbi.nlm.nih.gov/pubmed/21918508.

Hart, B. L. (1988). "Biological basis of the behavior of sick animals". In: Neurosci Biobehav Rev 12.2, pp. 123-37. ISSN: 0149-7634 (Print) 01497634. URL: https://www.ncbi.nlm.nih.gov/pubmed/3050629.

Hsu, P. D., Lander, E. S., and Zhang, F. (2014). "Development and applications of CRISPR-Cas9 for genome engineering". In: Cell 157.6, pp. 126278. ISSN: 1097-4172 (Electronic) 0092-8674. DOI: 10.1016/j .cell.2014. 05.010. URL: https://www.ncbi.nlm.nih.gov/pubmed/24906146.

Hunskaar, S. and Hole, K. (1987). "The formalin test in mice: dissociation between inflammatory and non-inflammatory pain". In: Pain 30.1, pp. 10314. ISSN: 0304-3959 (Print) 0304-3959. URL: https : //www.ncbi.nlm.nih. gov/pubmed/3614974.

Ji, R. R., Chamessian, A., and Zhang, Y. Q. (2016). "Pain regulation by nonneuronal cells and inflammation". In: Science 354.6312 , pp. 572-577. ISSN: 1095-9203 (Electronic) 0036-8075. DOI: 10.1126/science.aaf8924. URL: https://www.ncbi.nlm.nih.gov/pubmed/27811267.

Johansen, J. P., Fields, H. L., and Manning, B. H. (2001). "The affective component of pain in rodents: direct evidence for a contribution of the anterior cingulate cortex". In: Proc Natl Acad Sci U S A 98.14, pp. 807782. ISSN: 0027-8424 (Print) 0027-8424. DOI: 10.1073/pnas . 141218998. URL: https://www.ncbi.nlm.nih.gov/pubmed/11416168.

Johnson, J. D., O'Connor, K. A., Deak, T., Stark, M., Watkins, L. R., and Maier, S. F. (2002). "Prior stressor exposure sensitizes LPS-induced cytokine production". In: Brain Behav Immun 16.4, pp. 461-76. ISSN: 08891591 (Print) 0889-1591. URL: https://www.ncbi.nlm.nih.gov/pubmed/ 12096891.

Katona, C., Peveler, R., Dowrick, C., Wessely, S., Feinmann, C., Gask, L., Lloyd, H., Williams, A. C., and Wager, E. (2005). "Pain symptoms in 
depression: definition and clinical significance". In: Clin Med (Lond) 5.4, pp. 390-5. ISSN: 1470-2118 (Print) 1470-2118. URL: https : //www.ncbi . nlm.nih.gov/pubmed/16138496.

Kent, S., Tom, C., and Levine, S. (1997). "Effect of Interleukin-1beta on Pituitary-Adrenal Responses and Body Weight in Neonatal Rats: Interaction with Maternal Deprivation". In: Stress 1.4, pp. 213-230. ISSN: 16078888 (Electronic) 1025-3890. URL: https : / / www .ncbi.nlm.nih.gov/ pubmed/9787246.

Konsman, J. P. (2016). "Immune-to-brain signaling and substrates of altered behavior during inflammation". In: Neuroimmunol Neuroinflammation 3, pp. 207-14.

Konsman, J. P., Luheshi, G. N., Bluthe, R. M., and Dantzer, R. (2000). "The vagus nerve mediates behavioural depression, but not fever, in response to peripheral immune signals; a functional anatomical analysis". In: Eur J Neurosci 12.12, pp. 4434-46. ISSN: 0953-816X (Print) 0953-816X. URL: https://www.ncbi.nlm.nih.gov/pubmed/11122354.

Krashes, M. J., Koda, S., Ye, C., Rogan, S. C., Adams, A. C., Cusher, D. S., Maratos-Flier, E., Roth, B. L., and Lowell, B. B. (2011). "Rapid, reversible activation of AgRP neurons drives feeding behavior in mice". In: J Clin Invest 121.4, pp. 1424-8. ISSN: 1558-8238 (Electronic) 0021-9738 (Linking). DOI: 10.1172/JCI46229. URL: https://www.ncbi.nlm.nih.gov/pubmed/ 21364278.

Land, B. B., Bruchas, M. R., Schattauer, S., Giardino, W. J., Aita, M., Messinger, D., Hnasko, T. S., Palmiter, R. D., and Chavkin, C. (2009). "Activation of the kappa opioid receptor in the dorsal raphe nucleus mediates the aversive effects of stress and reinstates drug seeking". In: Proc Natl Acad Sci US A 106.45, pp. 19168-73. ISSN: 1091-6490 (Electronic) 0027-8424 (Linking). DOI: 10.1073/pnas .0910705106. URL: https : // www.ncbi.nlm.nih.gov/pubmed/19864633.

Langford, D. J., Bailey, A. L., Chanda, M. L., Clarke, S. E., Drummond, T. E., Echols, S., Glick, S., Ingrao, J., Klassen-Ross, T., Lacroix-Fralish, M. L., Matsumiya, L., Sorge, R. E., Sotocinal, S. G., Tabaka, J. M., Wong, D., Maagdenberg, A. M. van den, Ferrari, M. D., Craig, K. D., and Mogil, J. S. (2010). "Coding of facial expressions of pain in the laboratory mouse". In: Nat Methods 7.6, pp. 447-9. ISSN: 1548-7105 (Electronic) 1548-7091. DOI: 10.1038/nmeth.1455. URL: https://www.ncbi.nlm.nih.gov/pubmed/ 20453868 .

Luquet, S., Perez, F. A., Hnasko, T. S., and Palmiter, R. D. (2005). "NPY/AgRP neurons are essential for feeding in adult mice but can be ablated in neonates". In: Science 310.5748, pp. 683-5. ISSN: 1095-9203 (Electronic) 0036-8075 (Linking). DOI: 10.1126/science.1115524. URL: https://www.ncbi.nlm.nih.gov/pubmed/16254186.

Mahler, S. V. and Aston-Jones, G. (2018). "CNO Evil? Considerations for the Use of DREADDs in Behavioral Neuroscience". In: Neuropsychophar- 
macology 43.5, pp. 934-936. ISSN: 1740-634X (Electronic) 0893-133X. DOI: 10 . 1038 /npp . 2017 . 299. URL: https : / / www . ncbi .nlm . nih . gov/ pubmed/29303143.

McCoy, E. S., Taylor-Blake, B., and Zylka, M. J. (2012). "CGRPalphaexpressing sensory neurons respond to stimuli that evoke sensations of pain and itch". In: PLoS One 7.5, e36355. ISSN: 1932-6203 (Electronic) 1932-6203. DOI: $10.1371 /$ journal pone.0036355. URL: https : //www . ncbi.nlm.nih.gov/pubmed/22563493.

McNamara, C. R., Mandel-Brehm, J., Bautista, D. M., Siemens, J., Deranian, K. L., Zhao, M., Hayward, N. J., Chong, J. A., Julius, D., Moran, M. M., and Fanger, C. M. (2007). "TRPA1 mediates formalin-induced pain". In: Proc Natl Acad Sci U S A 104.33, pp. 13525-30. ISSN: 0027-8424 (Print) 0027-8424. DOI: $10.1073 /$ pnas .0705924104. URL: https ://www.ncbi . nlm.nih.gov/pubmed/17686976.

Murakami, M., Naraba, H., Tanioka, T., Semmyo, N., Nakatani, Y., Kojima, F., Ikeda, T., Fueki, M., Ueno, A., Oh, S., and Kudo, I. (2000). "Regulation of prostaglandin E2 biosynthesis by inducible membrane-associated prostaglandin E2 synthase that acts in concert with cyclooxygenase-2". In: J Biol Chem 275.42, pp. 32783-92. ISSN: 0021-9258 (Print) 0021-9258. DOI: $10.1074 /$ jbc.M003505200. URL: https://www.ncbi.nlm.nih.gov/ pubmed/10869354.

Murray, M. J. and Murray, A. B. (1979). "Anorexia of infection as a mechanism of host defense". In: Am J Clin Nutr 32.3, pp. 593-6. ISSN: 00029165 (Print) 0002-9165. DOI: $10.1093 / \mathrm{ajcn} / 32$.3 .593. URL: https : //www.ncbi.nlm.nih.gov/pubmed/283688.

Neugebauer, V. (2015). "Amygdala pain mechanisms". In: Handb Exp Pharmacol 227, pp. 261-84. ISSN: 0171-2004 (Print) 0171-2004. DOI: $10.1007 / 978-$ 3-662-46450-2_13. URL: https : //www.ncbi.nlm.nih.gov/pubmed/ 25846623.

Norgren, R. and Leonard, C. M. (1971). "Taste pathways in rat brainstem". In: Science 173.4002, pp. 1136-9. ISSN: 0036-8075 (Print) 0036-8075. URL: https://www.ncbi.nlm.nih.gov/pubmed/4329178.

Palmiter, R. D. (2018). "The Parabrachial Nucleus: CGRP Neurons Function as a General Alarm". In: Trends Neurosci 41.5, pp. 280-293. ISSN: 1878108X (Electronic) 0166-2236. DOI: 10.1016/j.tins.2018.03.007. URL: https://www.ncbi.nlm.nih.gov/pubmed/29703377.

Paues, J., Engblom, D., Mackerlova, L., Ericsson-Dahlstrand, A., and Blomqvist, A. (2001). "Feeding-related immune responsive brain stem neurons: association with CGRP". In: Neuroreport 12.11, pp. 2399-403. ISSN: 0959-4965 (Print) 0959-4965. URL: https : / / www . ncbi .nlm . nih . gov/ pubmed/11496118.

Price, D. D. (2000). "Psychological and neural mechanisms of the affective dimension of pain". In: Science 288.5472, pp. 1769-72. ISSN: 0036-8075 
(Print) 0036-8075. URL: https : / / www . ncbi.nlm . nih.gov/pubmed / 10846154.

Qian, S., Chen, H., Weingarth, D., Trumbauer, M. E., Novi, D. E., Guan, X., Yu, H., Shen, Z., Feng, Y., Frazier, E., Chen, A., Camacho, R. E., Shearman, L. P., Gopal-Truter, S., MacNeil, D. J., Van der Ploeg, L. H., and Marsh, D. J. (2002). "Neither agouti-related protein nor neuropeptide $\mathrm{Y}$ is critically required for the regulation of energy homeostasis in mice". In: Mol Cell Biol 22.14, pp. 5027-35. ISSN: 0270-7306 (Print) 0270-7306 (Linking). URL: https://www.ncbi.nlm.nih.gov/pubmed/12077332.

Rainville, P., Duncan, G. H., Price, D. D., Carrier, B., and Bushnell, M. C. (1997). "Pain affect encoded in human anterior cingulate but not somatosensory cortex". In: Science 277.5328, pp. 968-71. ISSN: 0036-8075 (Print) 0036-8075. URL: https : / / www . ncbi .nlm . nih . gov/pubmed/ 9252330.

Richard, S., Engblom, D., Paues, J., Mackerlova, L., and Blomqvist, A. (2005). "Activation of the parabrachio-amygdaloid pathway by immune challenge or spinal nociceptive input: a quantitative study in the rat using Fos immunohistochemistry and retrograde tract tracing". In: J Comp Neurol 481.2, pp. 210-9. ISSN: 0021-9967 (Print) 0021-9967. DOI: 10.1002/ cne.20384. URL: https://www.ncbi.nlm.nih.gov/pubmed/15562506.

Russell, F. A., King, R., Smillie, S. J., Kodji, X., and Brain, S. D. (2014). "Calcitonin gene-related peptide: physiology and pathophysiology". In: Physiol Rev 94.4, pp. 1099-142. ISSN: 1522-1210 (Electronic) 0031-9333 (Linking). DOI: $10.1152 /$ physrev.00034.2013. URL: https://www.ncbi.nlm.nih. gov/pubmed/25287861.

Salmon, A. M., Damaj, M. I., Marubio, L. M., Epping-Jordan, M. P., MerloPich, E., and Changeux, J. P. (2001). "Altered neuroadaptation in opiate dependence and neurogenic inflammatory nociception in alpha CGRPdeficient mice". In: Nat Neurosci 4.4, pp. 357-8. ISSN: 1097-6256 (Print) 1097-6256 (Linking). DOI: 10.1038/86001. URL: https ://www.ncbi.nlm. nih.gov/pubmed/11276224.

Salmon, A. M., Damaj, M. I., Sekine, S., Picciotto, M. R., Marubio, L., and Changeux, J. P. (1999). "Modulation of morphine analgesia in alphaCGRP mutant mice". In: Neuroreport 10.4, pp. 849-54. ISSN: 0959-4965 (Print) 0959-4965 (Linking). URL: https : //www.ncbi.nlm.nih.gov/pubmed/ 10208559.

Saper, C. B., Romanovsky, A. A., and Scammell, T. E. (2012). "Neural circuitry engaged by prostaglandins during the sickness syndrome". In: Nat Neurosci 15.8, pp. 1088-95. ISSN: 1546-1726 (Electronic) 1097-6256. DOI: 10.1038/nn . 3159. URL: http : //www . ncbi .nlm . nih . gov/pubmed/ 22837039.

Sapolsky, R. M. and Meaney, M. J. (1986). "Maturation of the adrenocortical stress response: neuroendocrine control mechanisms and the stress hypore- 
sponsive period". In: Brain Res 396.1, pp. 64-76. ISSN: 0006-8993 (Print) 0006-8993. URL: https://www.ncbi.nlm.nih.gov/pubmed/3011218.

Schwaber, J. S., Sternini, C., Brecha, N. C., Rogers, W. T., and Card, J. P. (1988). "Neurons containing calcitonin gene-related peptide in the parabrachial nucleus project to the central nucleus of the amygdala". In: $J$ Comp Neurol 270.3, pp. 416-26, 398-9. ISSN: 0021-9967 (Print) 0021-9967. URL: https://www.ncbi.nlm.nih.gov/pubmed/2836477.

Schweimer, J. V. and Ungless, M. A. (2010). "Phasic responses in dorsal raphe serotonin neurons to noxious stimuli". In: Neuroscience 171.4, pp. 120915. ISSN: 1873-7544 (Electronic) 0306-4522 (Linking). DOI: 10.1016/ j . neuroscience.2010.09.058. URL: https : //www.ncbi.nlm.nih.gov/ pubmed/20888395.

Shinohara, K., Watabe, A. M., Nagase, M., Okutsu, Y., Takahashi, Y., Kurihara, H., and Kato, F. (2017). "Essential role of endogenous calcitonin gene-related peptide in pain-associated plasticity in the central amygdala". In: Eur J Neurosci 46.6, pp. 2149-2160. ISSN: 1460-9568 (Electronic) 0953816X. DOI: 10.1111/ejn.13662. URL: https://www.ncbi.nlm.nih.gov/ pubmed/28833700.

Singh, Anand Kumar, Zajdel, Joanna, Mirrasekhian, Elahe, Almoosawi, Nader, Frisch, Isabell, Klawonn, Anna M, Jaarola, Maarit, Fritz, Michael, and Engblom, David (2017). "Prostaglandin-mediated inhibition of serotonin signaling controls the affective component of inflammatory pain". In: $J$ Clin Invest 127.4, pp. 1370-1374.

Sorrells, S. F., Caso, J. R., Munhoz, C. D., and Sapolsky, R. M. (2009). "The stressed CNS: when glucocorticoids aggravate inflammation". In: Neuron 64.1, pp. 33-9. ISSN: 1097-4199 (Electronic) 0896-6273. DOI: $10.1016 / \mathrm{j}$. neuron.2009.09.032. URL: https://www.ncbi.nlm.nih.gov/pubmed/ 19840546.

Spangler, S. M. and Bruchas, M. R. (2017). "Optogenetic approaches for dissecting neuromodulation and GPCR signaling in neural circuits". In: Curr Opin Pharmacol 32, pp. 56-70. ISSN: 1471-4973 (Electronic) 1471-4892. DOI: $10.1016 /$ j.coph.2016.11.001. URL: https://www.ncbi.nlm.nih. gov/pubmed/27875804.

Stachniak, T. J., Ghosh, A., and Sternson, S. M. (2014). "Chemogenetic synaptic silencing of neural circuits localizes a hypothalamus->midbrain pathway for feeding behavior". In: Neuron 82.4, pp. 797-808. ISSN: 10974199 (Electronic) 0896-6273. DOI: 10.1016/j . neuron. 2014.04.008. URL: https://www.ncbi.nlm.nih.gov/pubmed/24768300.

Stanton, M. E., Gutierrez, Y. R., and Levine, S. (1988). "Maternal deprivation potentiates pituitary-adrenal stress responses in infant rats". In: Behav Neurosci 102.5, pp. 692-700. ISSN: 0735-7044 (Print) 0735-7044. URL: https://www.ncbi.nlm.nih.gov/pubmed/3196438.

Stanton, M. E., Wallstrom, J., and Levine, S. (1987). "Maternal contact inhibits pituitary-adrenal stress responses in preweanling rats". In: Dev 
Psychobiol 20.2, pp. 131-45. ISSN: 0012-1630 (Print) 0012-1630. DOI: 10. 1002/dev.420200204. URL: https://www.ncbi.nlm.nih.gov/pubmed/ 3582776.

Sternberg, N. and Hamilton, D. (1981). "Bacteriophage P1 site-specific recombination. I. Recombination between loxP sites". In: J Mol Biol 150.4, pp. 467-86. ISSN: 0022-2836 (Print) 0022-2836. URL: https://www.ncbi. nlm.nih.gov/pubmed/6276557.

Sugimoto, Y. and Narumiya, S. (2007). "Prostaglandin E receptors". In: J Biol Chem 282.16, pp. 11613-7. ISSN: 0021-9258 (Print) 0021-9258. DOI: 10.1074/ jbc.R600038200. URL: https : / / www . ncbi.nlm.nih.gov/ pubmed/17329241.

Sugimura, Y. K., Takahashi, Y., Watabe, A. M., and Kato, F. (2016). "Synaptic and network consequences of monosynaptic nociceptive inputs of parabrachial nucleus origin in the central amygdala". In: J Neurophysiol 115.6, pp. 2721-39. ISSN: 1522-1598 (Electronic) 0022-3077. DOI: 10 . 1152/jn.00946.2015. URL: https://www.ncbi.nlm.nih.gov/pubmed/ 26888105.

Teissier, A., Chemiakine, A., Inbar, B., Bagchi, S., Ray, R. S., Palmiter, R. D., Dymecki, S. M., Moore, H., and Ansorge, M. S. (2015). "Activity of Raphe Serotonergic Neurons Controls Emotional Behaviors". In: Cell Rep 13.9, pp. 1965-76. ISSN: 2211-1247 (Electronic). DOI: 10.1016/j.celrep. 2015. 10.061. URL: https://www.ncbi.nlm.nih.gov/pubmed/26655908.

Thomas, P. M., Nasonkin, I., Zhang, H., Gagel, R. F., and Cote, G. J. (2001). "Structure of the mouse calcitonin/calcitonin gene-related peptide alpha and beta genes". In: DNA Seq 12.2, pp. 131-5. ISSN: 1042-5179 (Print) 1026-7913. URL: https://www.ncbi.nlm.nih.gov/pubmed/11761712.

Tracey, K. J. (2002). "The inflammatory reflex". In: Nature 420.6917, pp. 8539. ISSN: 0028-0836 (Print) 0028-0836. DOI: 10.1038/nature01321. URL: https://www.ncbi.nlm.nih.gov/pubmed/12490958.

Urban, D. J. and Roth, B. L. (2015). "DREADDs (designer receptors exclusively activated by designer drugs): chemogenetic tools with therapeutic utility". In: Annu Rev Pharmacol Toxicol 55, pp. 399-417. ISSN: 15454304 (Electronic) 0362-1642. DOI: 10.1146/annurev-pharmtox-010814124803. URL: https://www.ncbi.nlm.nih.gov/pubmed/25292433.

Waselus, M., Valentino, R. J., and Van Bockstaele, E. J. (2011). "Collateralized dorsal raphe nucleus projections: a mechanism for the integration of diverse functions during stress". In: J Chem Neuroanat 41.4, pp. 26680. ISSN: 1873-6300 (Electronic) 0891-0618 (Linking). DOI: 10.1016/ j . jchemneu . 2011.05 .011. URL: https : //www . ncbi.nlm.nih.gov/ pubmed/21658442.

Wilhelms, D. B., Dock, H., Brito, H. O., Pettersson, E., Stojakovic, A., Zajdel, J., Engblom, D., Theodorsson, E., Hammar, M. L., and Spetz Holm, A. E. (2018). "CGRP Is Critical for Hot Flushes in Ovariectomized Mice". In: Front Pharmacol 9, p. 1452. ISSN: 1663-9812 (Print) 1663-9812 (Linking). 
DOI: $10.3389 /$ fphar.2018.01452. URL: https : //wwW.ncbi.nlm.nih. gov/pubmed/30662401.

Wing, E. J. and Young, J. B. (1980). "Acute starvation protects mice against Listeria monocytogenes". In: Infect Immun 28.3, pp. 771-6. ISSN: 00199567 (Print) 0019-9567. URL: https://www.ncbi.nlm.nih.gov/pubmed/ 6772566.

Witek-Janusek, L. (1988). "Pituitary-adrenal response to bacterial endotoxin in developing rats". In: Am J Physiol 255.4 Pt 1, E525-30. ISSN: 00029513 (Print) 0002-9513. DOI: 10.1152/ajpendo.1988.255.4.E525. URL: https://www.ncbi.nlm.nih.gov/pubmed/2845803.

Wortley, K. E., Anderson, K. D., Yasenchak, J., Murphy, A., Valenzuela, D., Diano, S., Yancopoulos, G. D., Wiegand, S. J., and Sleeman, M. W. (2005). "Agouti-related protein-deficient mice display an age-related lean phenotype". In: Cell Metab 2.6, pp. 421-7. ISSN: 1550-4131 (Print) 15504131 (Linking). DOI: 10.1016/j.cmet.2005.11.004. URL: https://www. ncbi.nlm.nih.gov/pubmed/16330327.

Wu, Q., Clark, M. S., and Palmiter, R. D. (2012). "Deciphering a neuronal circuit that mediates appetite". In: Nature 483.7391, pp. 594-7. ISSN: 14764687 (Electronic) 0028-0836. DOI: 10 .1038/nature10899. URL: https: //www.ncbi.nlm.nih.gov/pubmed/22419158.

Zajdel, Joanna, Sköld, Johan, Levinsson, Julia, Ullah, Redoy, Jaarola, Marit, Singh, Anand Kumar, and Engblom, David (2019). "Calcitonin gene related peptide alpha is dispensable for many danger-related motivational responses". In: Manuscript.

Zajdel, Joanna, Zager, Adriano, Blomqvist, Anders, Engblom, David, and Shionoya, Kiseko (2019). "Acute maternal separation potentiates the gene expression and corticosterone response induced by inflammation". In: Brain Behav Immun 77, pp. 141-149.

Zhang, L., Hoff, A. O., Wimalawansa, S. J., Cote, G. J., Gagel, R. F., and Westlund, K. N. (2001). "Arthritic calcitonin/alpha calcitonin gene-related peptide knockout mice have reduced nociceptive hypersensitivity". In: Pain 89.2-3, pp. 265-73. ISSN: 0304-3959 (Print) 0304-3959 (Linking). URL: https://www.ncbi.nlm.nih.gov/pubmed/11166483. 


\section{Papers}

The papers associated with this thesis have been removed for copyright reasons. For more details about these see:

http://urn.kb.se/resolve?urn=urn:nbn:se:liu:diva-156181 


\section{FACULTY OF MEDICINE AND HEALTH SCIENCES}

Linköping University Medical Dissertation No. 1679, 2019

Department of Clinical and Experimentál Medicine

Center for Social and Affective Neuroscience:

Linköping University
SE-581 83 Linköping, Sweden

www.liu.se

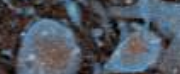

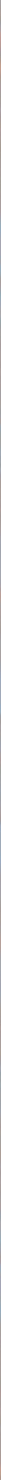

